\title{
Dam and wet-screened concrete creep in compression: in situ experimental results and creep strains prediction using model $\mathrm{B3}$ and composite models
}

\author{
C. Serra $\square$ - A. L. Batista N. Monteiro Azevedo
}

Received: 20 July 2015 / Accepted: 14 February 2016/Published online: 29 February 2016

(C) RILEM 2016

\begin{abstract}
This paper proposes a methodology for the prediction of the compressive creep strains of dam concrete based on wet-screened experimental results at constant elevated temperature conditions measured in situ. Due to its large aggregate dimensions, the experimental characterization of dam concrete has particular constraints. The wet-screened concrete, obtained by sieving the aggregates larger than a given dimension, after mixing, is used to cast standard specimens and to embed monitoring devices. An experimental in situ installation using creep cells was used to obtain the compressive creep strain development over time for the maturing conditions of the dam core. The study of the effect of wet-screening procedure on creep in compression considers three types of concrete, dam concrete and two wet-screened concretes tested at three loading ages, 28, 90 and 365 days. The comparison between different types of concrete at different maturing conditions requires the definition of a reference state given by the maturity method, using the equivalent age, and relies on the fit of compressive creep strains to the RILEM recommended model B3. To take into account the effect of the aggregate content on the deformability properties of dam concrete, an
\end{abstract}

C. Serra $(\bowtie) \cdot$ A. L. Batista · N. Monteiro Azevedo National Laboratory for Civil Engineering, Av. do Brasil 101, Lisbon 1700-066, Portugal

e-mail: cserra@lnec.pt equivalent two-phase composite model was applied. The equivalent composite model considered the equivalent matrix as the wet-screened concrete and the inclusions as the larger aggregates that are removed during the wet-screening procedure. Predictions obtained with the composite model are close to the dam concrete experimental results, for the tested loading ages.

Keywords Dam concrete - Wet-screened concrete . Creep in compression - In situ tests · Model B3 .

Composite models

\section{Introduction}

Dam concrete is considered to be a mass concrete with a poor binder content, $100-300 \mathrm{~kg} / \mathrm{m}^{3}$, and with large admixtures dosage, up to $50 \%$ of the cement replacement [1]. It has a large aggregate content and the maximum size of aggregate (MSA) can reach up to $150 \mathrm{~mm}[2,3]$. The combination of the temperature gradients due to heat dissipation, the slow mechanical property development and, therefore, the cracking risk at early ages are the main concerns of mass concrete $[2,3]$. For an accurate cracking risk assessment it is necessary to determine the mechanical properties development, as well as the stress development during the first year [4, 6]. Moreover, to interpret the dam structural behaviour for several decades, long-term instantaneous and time-dependent properties are key 
to assess the overall safety of the structure and make lifetime predictions [7-10].

Dam concrete experimental characterization has particular challenges. The use of large aggregates in the production of dam concrete implies the use of large specimens. It is common practice to remove the larger aggregates and, with the remaining concrete, cast smaller specimens and embed monitoring devices [1, $3]$. The concrete with a smaller maximum aggregate size, wet-screened concrete, is widely used for quality control. The need of reliable relationships between dam concrete and wet-screened concrete is required for design, concrete quality control during construction, monitoring and data analysis and for safety control throughout service life [1-3].

As mentioned, dam concrete is usually made with large size coarse aggregates, for which common specimen dimension and laboratory equipment are not suitable. As a result, concrete quality control and concrete characterization are commonly based on results from wet-screened concrete obtained from the full-mixed structural mass concrete $[1,2]$ as the structural concrete. In addition, several embedded monitoring devices are cast with the wet-screened concrete. Wet-screened concrete is obtained by removing the larger aggregates, usually greater than $38 \mathrm{~mm}$ (\#38 wet-screened concrete), from the original concrete mix, while is still fresh. Due to its particular application, its prescribed composition [11] and despite the extensive experimental work and research developed worldwide concerning concrete, correlations between the behaviour of wet-screened and on site concrete are limited to instantaneous behaviour [12-17]. ACI Committee 207, for example, refers briefly that the compressive strength of large specimens of full mass concrete is 80 to $90 \%$ of its wetscreened concrete, evaluated in smaller specimens [3].

Experimental testing of the produced concrete carried out for quality control and for property characterization is essential for this type of structures. Analytical and empirical models are used for the prediction of the instantaneous mechanical properties $[12,18-20]$ but only statistical correlations are still available for the comparison of delayed behaviour of the two types of concrete.

Prediction of concrete delayed behaviour goes back to the beginning of the twentieth century, when Woolson and Hatt registered what it seemed to be a "flow" of concrete [21]. Since then much has been found about the physical nature and mechanisms of the phenomena [21-24] and several mathematical laws to determine the relationship between strain and stress over time are available [19, 25-29]. However, the composition of dam concrete, with large fly ash content and large aggregates, requires more research regarding the hydration and aging processes and the calibration of the existing model with specific experimental results [30-33].

This paper presents the prediction of the compressive creep strain development of dam concrete based on the in situ experimental results of wet-screened concrete using the fit to the RILEM recommended model B3 [34] considering maturity method concepts and a composite model. The experimental programme implied the installation of creep cells inside the dam's body and cast with dam concrete (MSA $=150 \mathrm{~mm}$ ) and two types of wet-screened concrete (MSA = $76 \mathrm{~mm}$ and MSA = $38 \mathrm{~mm}$ ). The compressive creep strain development was obtained for three loading ages considering the measured temperature of the dam's core. In order to obtain a reference state and comparable results between different creep cells, the maturity method was used.

An increase of temperature accelerates the cement hydration and the development of the instantaneous properties of concrete, such as strength [35, 36], modulus of elasticity and the creep strains development over time [29, 37], particularly for the early ages. The curing procedures and the moisture gradients inside the specimen can also influence the ultimate strengths [38] and delayed deformability properties $[37,39]$.

Composite models allow for the prediction of the deformability properties taking into account the concrete composition and considering concrete as coarse aggregate inclusions embedded in a matrix of mortar. Several authors proposed simple composite models for the determination of the instantaneous deformability properties [40-43] with specific applications [14, 44]. Adaptations of these models have been proposed also for the delayed deformability properties, namely the creep strain development over time [43, 45-48].

The wet-screening procedure implies a significant change in the composition of dam concrete. The methodology proposes the use of composite models for the prediction of the creep in compression of dam concrete considering a two-phase material model using the wet-screened concrete as an aging 
viscoelastic equivalent matrix and the removed larger aggregates as the elastic inclusions.

The prediction of the dam concrete creep strains in compression, using the equivalent composite model and based on the wet-screened test results, show a good agreement with the experimental measurements for several loading ages.

\section{Prediction of dam concrete creep in compression}

\subsection{Proposed methodology}

The proposed methodology for the prediction of in situ dam concrete creep strains in compression is based on a composite model in which the equivalent matrix is the wet-screened concrete and the inclusions are the removed aggregate in the wet-screening procedure. The study is divided into three main parts: (i) an experimental study for the evaluation of the compressive creep strains obtained in situ of the dam concrete and the two wet-screened concretes (\#76 and \#38 concrete); (ii) the fit of the experimental results to model B3 considering the measured temperature for each type of concrete to obtain a reference temperature state; and, (iii) the prediction of the dam concrete compressive creep strains based on the compressive creep strains of the wet-screened concrete using an equivalent two-phase composite model (Composite \#76-Dam and Composite \#38-Dam). Figure 1 presents the schematic view of the proposed procedure for the validation of the equivalent composite model for the prediction of dam concrete compressive creep strains.

The experimental programme was defined in order to measure the development of the in situ compressive creep strains of dam concrete and of two wet-screened concretes, the concrete with MSA=76 mm (\#76 concrete) and the concrete with MSA $=38 \mathrm{~mm}(\# 38$ concrete). The \#76 and \#38 concretes were obtained by removing the aggregates larger than 76 and $38 \mathrm{~mm}$, respectively. The compressive creep strains were measured in creep cells, concrete specimens embedded in the dam's core (Sect. 2.2).

The comparison between the different test conditions (such as the temperature variations) was achieved by fitting the test results to the model B3 at constant elevated temperatures considering the equivalent age method (Sect. 2.3.2). An optimization procedure considering the equivalent age method allowed

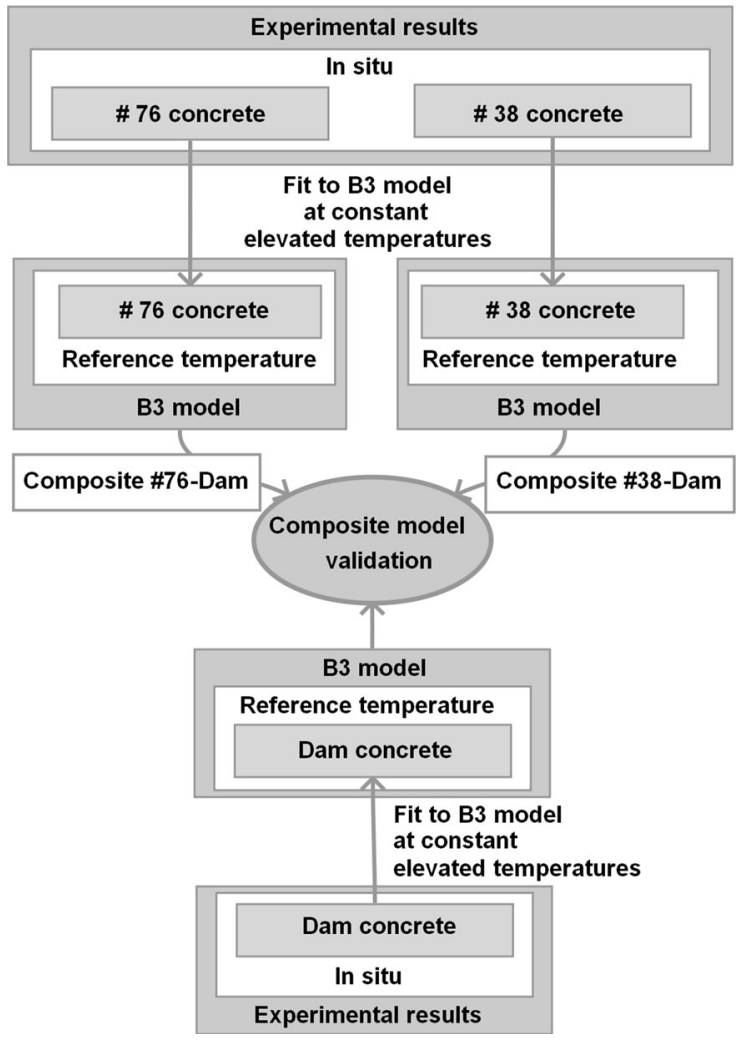

Fig. 1 Procedure for the validation of the equivalent composite model for dam concrete compressive creep strains

for evaluation of the model parameters at reference temperature state, since the temperature variations are taken into account.

The prediction of dam concrete delayed behaviour was obtained using an equivalent two-phase composite model (Sect. 2.3.3). The proposed innovation of this paper is to consider the wet-screened concrete, obtained from the dam concrete as an equivalent aging viscoelastic matrix and the removed aggregates as the elastic inclusions.

A simple parallel and series composite model and its adaptation to aging materials considering the ageadjusted effective modulus method (Sect. 2.3.1) was used [47]. The input parameters are the volume fractions of equivalent matrix (wet-screened concrete) and the inclusions (removed aggregates) and the creep compliance of each wet-screened concrete. Since two type of wet-screened concretes were tested, two composite models were developed: Composite \#76Dam, using the test results of the concrete obtained from sieving the aggregates larger than $76 \mathrm{~mm}$ and 
Composite \#38-Dam, using the \#38 mm wet-screened concrete test results. Each composite prediction was compared with the model B3 fit of the experimental results of dam concrete.

In the following sections the experimental setup, the general concepts of delayed behaviour of concrete, the methods of analysis and the used models are described. The methods of analysis include the ageadjusted effective modulus method [49], the model B3, its extension to basic creep at constant elevated temperature [29] and the two-phase composite model proposed by Granger and Bažant [47]) using the ageadjusted effective modulus method for the evaluation of the delayed strains of the composite.

\subsection{Experimental setup for in situ testing using creep cells}

The in situ characterization of dam concrete relies on a specific experimental setup based on creep cells. Creep cells (CC) are cylindrical specimens placed inside the dam, cast into expanded polystyrene (EPS) hollow cylinders (Fig. 2). The creep cells are subjected to the same thermohygrometric conditions as the structural concrete since its top face is connected to

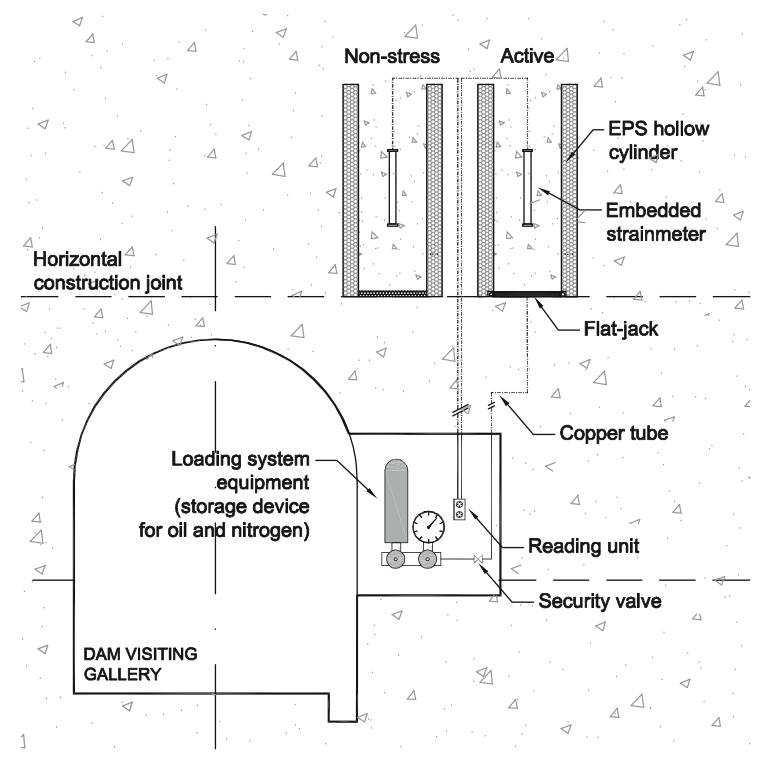

Fig. 2 General view of the active and non-stress creep cells and of the loading system the dam concrete and are cast and completely covered with the surrounding lift.

Figure 2 shows a general view of a creep cell setup. To separate the effect of applied stress and evaluate the creep strains development, two identical creep cells are installed, an active cell and a free or nonstress cell, placed next to each other. The loading system is connected to the active creep cell, therefore, both the shrinkage strains, the thermal strains and the stress derived strains can be measured (total strains). The non-stress creep cell, installed without a loading system, measures only the shrinkage and thermal strains (non-stress strains).

The creep cells are placed one or two lifts above a visiting gallery of the dam, where the external loading system is placed. A flat-jack, placed in the basis of the active cells, filled with oil and controlled by the loading system, applies a distributed load to the specimen. The oil pressure is controlled by a closed hydraulic system which allows fast pressure variations (for modulus of elasticity tests) and can maintain a constant oil pressure (for compression creep tests). Each active creep cell has its individual loading system. The pressure is kept constant over time with the aid of a pressure storage device where nitrogen gas compensates the small pressure decay due to creep deformation of the specimen [21] (Fig. 2). The strain variations are measured with Carlson strainmeters placed inside each creep cell connected to a reading unit located at the gallery of the dam.

The experimental creep compliance, $J_{\exp }\left(t, t^{\prime}\right)$, at time $t$ for a loading age of $t^{\prime}$, considered to be a measurement of creep if the stress is kept constant, are obtained by subtracting the free strains, measured in the non-stress cell, from the total strains, measured in the active cell, and dividing by the applied stress (Eq. 1).

$J_{\exp }\left(t, t^{\prime}\right)=\frac{\varepsilon_{\text {active }}\left(t, t^{\prime}\right)-\varepsilon_{\text {non-stress }}\left(t, t^{\prime}\right)}{\sigma\left(t^{\prime}\right)}$

If stress is maintained constant since the first load and the temperature is kept constant, one can compare experimental creep compliance, $J_{\exp }\left(t, t^{\prime}\right)$, with theoretical creep compliance, $J\left(t, t^{\prime}\right)$.

The advantage of creep cells is the possibility to characterize the deformability properties over time in the environmental conditions of the dam's core. Also allows the testing of large specimens, suited for the 
dam concrete and its large aggregates, since the surrounding mass concrete is used as the reaction frame. This type of experimental installation was developed in the past by the National Laboratory for Civil Engineering (LNEC) [77, 78] and, for this particular study, several technical improvements were implemented. The main new features are: (i) the use of a standard flat-jack (with rigid interface platens), larger in diameter $(\phi)$ and increasing the $\phi$-MSA ratio of dam concrete specimen (Fig. 5); (ii) the use of three measurement devices in the dam concrete specimen for a more reliable reading; and, (iii) the use of expanded polystyrene (EPS) hollow cylinder as the mould to separate the concrete specimen from the dam's body (instead of metallic moulds use in the past, with higher rigidity). The procedure for the experimental installation was: (i) placement of the loading system (the storage device in the visiting gallery and the flat-jack of each creep cells) and purge the hydraulic circuit; (ii) placement of the measuring devices inside the active and non-active cells and the electric cables; (iii) wet-screening of the dam concrete; (iv) cast of each creep cell with dam concrete and wet-screened concrete; (v) setting the initial reading values in each creep cell; (vi) cast the surrounding lift.

\subsection{Methods of analysis and analytical models}

\subsubsection{Creep strains}

Generally, the delayed behaviour of concrete is described as a total strain, $\varepsilon\left(t, t^{\prime}\right)$, resultant of a stress, $\sigma\left(t^{\prime}\right)$, applied at the age of $t^{\prime}$ and kept constant until $t$, and an hygrothermal strain, $\varepsilon^{0}(t)$, such as drying shrinkage, thermal or chemical strains.

$$
\varepsilon\left(t, t^{\prime}\right)=\varepsilon^{i}\left(t^{\prime}\right)+\varepsilon^{c}\left(t, t^{\prime}\right)+\varepsilon^{0}(t)
$$

Considering that no cracking occurs, the stressdependent strain can be expressed as the sum of an instantaneous strain, $\varepsilon^{i}\left(t^{\prime}\right)$ and of a creep strain, $\varepsilon^{c}\left(t, t^{\prime}\right)$. The instantaneous and creep strains can be expressed as a function of stress, obtaining the creep compliance, $J\left(t, t^{\prime}\right)$.

$$
\varepsilon\left(t, t^{\prime}\right)=J\left(t, t^{\prime}\right) \sigma\left(t^{\prime}\right)=\varepsilon^{i}\left(t^{\prime}\right)+\varepsilon^{c}\left(t, t^{\prime}\right)
$$

$J\left(t, t^{\prime}\right)=\frac{1}{E\left(t^{\prime}\right)}+\frac{\varepsilon^{c}\left(t, t^{\prime}\right)}{\sigma\left(t^{\prime}\right)}$

The stress, $\sigma\left(t, t^{\prime}\right)$, obtained from a given strain, $\varepsilon\left(t^{\prime}\right)$ is related to the relaxation function.

$\sigma\left(t, t^{\prime}\right)=R\left(t, t^{\prime}\right) \varepsilon\left(t^{\prime}\right)$

which can be approximated, as proposed by Bažant and Kim [50], by,

$$
\begin{gathered}
R\left(t, t^{\prime}\right)=\frac{0.992}{J\left(t, t^{\prime}\right)}-\frac{0.15}{J(t, t-1)}\left[\frac{J\left(t-\Delta t, t^{\prime}\right)}{J\left(t, t^{\prime}+\Delta t\right)}-1\right] \\
\Delta t=\frac{t-t^{\prime}}{2}
\end{gathered}
$$

The age-adjusted effective modulus method, AAEM method [49], based on the linear principle of superposition, is used for obtaining an approximate solution of the creep strains development by assuming that,

$$
\begin{aligned}
& \varepsilon\left(t, t^{\prime}\right)-\varepsilon^{0}(t)=\varepsilon_{0}+\varepsilon_{1} \phi\left(t, t^{\prime}\right), \quad t>t^{\prime} \\
& \sigma\left(t^{\prime}\right)=0, \quad t<t^{\prime}
\end{aligned}
$$

where $\varepsilon_{0}$ and $\varepsilon_{1}$ are given constants. The advantage of this method is that the creep analysis converts into an elastic analysis considering an incremental form,

$$
\Delta \sigma(t)=E^{\prime \prime}\left(t, t^{\prime}\right)\left(\Delta \varepsilon\left(t, t^{\prime}\right)-\Delta \varepsilon^{\prime \prime}\left(t, t^{\prime}\right)\right)
$$

in which,

$$
\begin{aligned}
& \Delta \varepsilon\left(t, t^{\prime}\right)=\varepsilon(t)-\varepsilon\left(t^{\prime}\right), \Delta \sigma\left(t, t^{\prime}\right)=\sigma(t)-\sigma\left(t^{\prime}\right) \\
& \Delta \varepsilon^{\prime \prime}\left(t, t^{\prime}\right)=\frac{\sigma\left(t^{\prime}\right)}{E\left(t^{\prime}\right)} \phi\left(t, t^{\prime}\right)+\varepsilon^{0}(t)-\varepsilon^{0}\left(t^{\prime}\right) \\
& E^{\prime \prime}\left(t, t^{\prime}\right)=\frac{E\left(t^{\prime}\right)}{1+\chi\left(t, t^{\prime}\right) \phi\left(t, t^{\prime}\right)} \\
& \phi\left(t, t^{\prime}\right)=J\left(t, t^{\prime}\right) E\left(t^{\prime}\right)-1 \\
& \chi\left(t, t^{\prime}\right)=\left(1-\frac{R\left(t, t^{\prime}\right)}{E\left(t^{\prime}\right)}\right)^{-1}-\frac{1}{\phi\left(t, t^{\prime}\right)}
\end{aligned}
$$

where $\phi\left(t, t^{\prime}\right)$ and $\chi\left(t, t^{\prime}\right)$ are, respectively, the creep coefficient and the age coefficient and $E^{\prime \prime}\left(t, t^{\prime}\right)$ is the age-adjusted effective modulus.

This method was used by [47] to introduce the aging viscoelasticity of concrete into a composite twophase model (Sect. 2.3.3). 


\subsubsection{Prediction model for the concrete creep strains}

Model B3, proposed by Bažant and Baweja [28, 29], describes creep compliance as the sum of the asymptotic elastic strains due to unit stress, $q_{1}$, the basic creep compliance, $C_{0}\left(t, t^{\prime}\right)$, and the drying creep compliance, $C_{d}\left(t, t_{0}, t^{\prime}\right)$ (Eq. 14). Its strong points are related to the fact that the creep compliance rate, $\dot{C}_{0}\left(t, t^{\prime}\right)$, is derived according to the guidelines of RILEM TC-107 [51], has been fitted from multidecade laboratory tests [52], is based on the micromechanics of aging considered in the solidification theory $[53,54]$ and has been shown to have lower coefficients of variation of errors for dam concrete [29].

$$
J\left(t, t^{\prime}\right)=q_{1}+C_{0}\left(t, t^{\prime}\right)+C_{d}\left(t, t^{\prime}, t_{0}\right)
$$

For the dam body, due to the large thickness of the dam and the slow water diffusion in concrete, only a small layer of the upstream and downstream (during construction) is subjected to cyclic drying and wetting [59] and the moisture exchange with the environment is small. For this reason, in this study, drying creep strains can be considered negligible [7, 60]. The basic creep compliance, $C_{0}\left(t, t^{\prime}\right)$, can be expressed as a linear combination of material parameters and timedependent variables.

$$
C_{0}\left(t, t^{\prime}\right)=q_{2} Q\left(t, t^{\prime}\right)+q_{3} \ln \left[1+\left(t-t^{\prime}\right)^{n}\right]+q_{4} \ln \left(\frac{t}{t^{\prime}}\right)
$$

where $Q\left(t, t^{\prime}\right)$ is a binomial integral with no analytical expression but can be approximated by Eqs. 16-19, with an error less than $1 \%$ for $n=0.1$ and $m=0.5$ for a large range of loading age and time under loading $[28,29]$.

$$
\begin{aligned}
& Q\left(t, t^{\prime}\right)=Q_{f}\left(t^{\prime}\right)\left[1+\left(\frac{Q_{f}\left(t^{\prime}\right)}{Z\left(t, t^{\prime}\right)}\right)^{r\left(t^{\prime}\right)}\right]^{-1 / r\left(t^{\prime}\right)} \\
& r\left(t^{\prime}\right)=1.7\left(t^{\prime}\right)^{0.12}+8 \\
& Z\left(t, t^{\prime}\right)=\left(t^{\prime}\right)^{-m} \ln \left[1+\left(t-t^{\prime}\right)^{n}\right] \\
& Q_{f}\left(t^{\prime}\right)=\left[0.086\left(t^{\prime}\right)^{2 / 9}+1.21\left(t^{\prime}\right)^{4 / 9}\right]^{-1}
\end{aligned}
$$

Considering a load duration, $\Delta t$, usually taken to be 0.01 days, the static modulus of elasticity yields from the creep compliance (Eq. 14),

$$
E\left(t^{\prime}\right)=\frac{1}{A_{0}+\frac{A_{1}}{\sqrt{t^{\prime}}}}
$$

where $A_{0}=q_{1}+q_{3} \ln \left(1+\Delta t^{n}\right) \quad$ and $\quad A_{1}=q_{2} \ln$ $\left(1+\Delta t^{n}\right)$.

Each term of the sum has a physical meaning: $q_{1}$ is the asymptotic elastic part, $q_{2}$ refers to aging viscoelasticity, $q_{3}$ refers to non-aging viscoelasticity and $q_{4}$ refers to aging flow. Since it is a linear combination of time-dependent variables, the fit to experimental data is easier than other creep models.

The temperature and moisture conditions have an important role in the development of the mechanical properties, especially on creep strains. The influence of temperature on the properties development is mainly ruled by the composition of the binder due to changes of cement hydration rate. The replacementof cement by fly ash is known to decrease the rate of property development [61-63] due to the late chemical reactions with the calcium silicates.

To model the effect of temperature variations in the hardening of concrete, several authors use the equivalent age method (or Arhenius maturity) [35] with equivalent activation energies, calibrated for tests at different temperatures, for different mechanical properties and different types of concrete [36, 64-66]. Particularly for the investigation of temperature effect on the creep of concrete, some experimental studies have been done [37, 67-69].

According to this method the original compliance (Eq. 15) yields a new expression (Eq. 21) to take into account constant elevated temperatures, $T(t)$, in degrees Celsius [29].

$$
\begin{aligned}
& C_{0}\left(t, t^{\prime}, T\right)=R_{T}\left[q_{2} Q\left(t_{T}, t_{e}^{\prime}\right)\right. \\
& \left.\quad+q_{3} \ln \left[1+\left(t_{T}-t_{e}^{\prime}\right)^{n}\right]+q_{4} \ln \left(\frac{t_{T}}{t_{e}^{\prime}}\right)\right]
\end{aligned}
$$

where $t_{e}^{\prime}$ and $t_{T}-t_{e}^{\prime}$ are the equivalent age and the equivalent loading time both with the respective activation energy, $U_{h}$, for the cement hydration reactions and $U_{c}$, for describing the acceleration of creep rate. $U_{c}^{\prime}$ refers to magnification of creep due to temperature increase, defined by the Eqs. (27-29).

$$
t_{e}^{\prime}=\int_{0}^{t^{\prime}} \beta_{T}(\tau) d \tau
$$


$t_{T}-t_{e}^{\prime}=\int_{t^{\prime}}^{t} \beta_{T}^{\prime}\left(\tau^{\prime}\right) d \tau^{\prime}$

$\beta_{T}=\exp \left[\frac{U_{h}}{R}\left(\frac{1}{T_{r e f}+273}-\frac{1}{T+273}\right)\right]$

$\beta_{T}^{\prime}=\exp \left[\frac{U_{c}}{R}\left(\frac{1}{T_{\text {ref }}+273}-\frac{1}{T+273}\right)\right]$

$R_{T}=\exp \left[\frac{U_{c}^{\prime}}{R}\left(\frac{1}{T_{r e f}+273}-\frac{1}{T+273}\right)\right]$

where $T_{r e f}$ is the reference temperature in degrees Celsius, $T$ is the measured temperature in degrees Celsius and $R$ is the gas constant $\left(8.31 \mathrm{~J} \mathrm{~K}^{-1} \mathrm{~mol}^{-1}\right)$ and, according to experimental fit to laboratory tests [29], the activation energies, $U_{h}, U_{c}^{\prime}$ and $U_{c}$, can be predicted by the following expressions:

$\frac{U_{h}}{R}=5000^{\circ} \mathrm{K}$

$\frac{U_{c}}{R}=3418[(w / c)(c)]^{-0.27}\left(f_{c, 28}\right)^{0.54}$

$\frac{U_{c}^{\prime}}{R}=0.18 \frac{U_{c}}{R}$

where the $w, c$ and $f_{c, 28}$ are the water content, the cement content and the compressive strength at the age of 28 days. In order to take into account the temperature effect of a specific concrete composition on the creep development, the activation energies can be adjusted to the obtained experimental results $[35,36]$.

\subsubsection{Composite model for the characterization of the deformability properties}

The second part of the study concerns the use of composite models to predict the delayed behaviour of concrete with different coarse aggregate contents.

The heterogeneity of concrete can be studied using models where the meso-structure is taken into account. The first composite models applied to concrete concerned the elastic behaviour using approaches based on uniaxial rheological models [41-43] and on homogenization models, such as the variational approach considering spherical inclusions (HashinShtrickman bounds) [70], the self-consistent model considering ellipsoidal inclusions [71] and the MoriTanaka method [72]. The prediction of the aging viscoelastic behaviour of the materials using composite model was developed with the work of Counto and Popovics [43, 48] and later with Granger, Bažant and Baweja [47, 73], based on the uniaxial rheological models, and, more recently, Sanahuja and Lavergne, using homogenization concepts $[74,75]$.

The chosen model is the two-phase coupled series and parallel composite model, described by Granger and Bažant [47], which considers the mortar as the aging viscoelastic material and the coarse aggregates as the elastic inclusions. The model is based in a simple uniaxial rheological model which is strongly related to the physical behaviour of the material. The extension to triaxial behaviour was developed later by Baweja et al. [73]. It is considered that a part of the mortar is placed in series with the aggregates (related with parameter $\alpha$ ) and another part is placed in parallel (related with parameter $\beta$ ) (Fig. 3b). The series portion can be perceived as the amount of mortar that separates the coarse aggregates avoiding their direct contact and the parallel portion corresponds to the remaining volume between the aggregates.

The composite model estimates the modulus of elasticity of the composite material based on the modulus of elasticity of the mortar, $E_{m}$, the modulus of elasticity of the aggregate, $E_{a}$, its respective unit volume, $V_{a}$ and the proportion of mortar placed in series and in parallel defined by $\beta$ (Eq. 30).

$\frac{1}{E_{c}}=\frac{1-\beta}{E_{m}}+\frac{\beta}{\alpha E_{a}+(1-\alpha) E_{m}}$

where $\alpha \beta=V_{a}$.

The physical meaning of the free parameter $\beta$ is related to the amount of paste coupled in series and the product $\alpha \beta$ is the volume of aggregate per unit volume of concrete, $\mathrm{V}_{a}$. When $\beta$ is equal to 1.0 (Fig. $3 \mathrm{a}$ ), the model derives into Voigt model (purely parallel model [43]) which can be related the maximum compactness, $V_{a, \max }$. The maximum compactness of aggregate is related to the aggregate size distribution and corresponds to the volume of aggregate in the mix necessary to obtain the most compact packing [76]. If the aggregates are in contact with each other, it is expected that the series portion is null and that the composite model turn into a parallel model $(\beta=1$, Fig. 3b). An example of this type of concrete is the prepacked or preplaced aggregate concrete in which the aggregates are first placed in the forms and then the 
(a) $V_{a}<V_{a}$,max

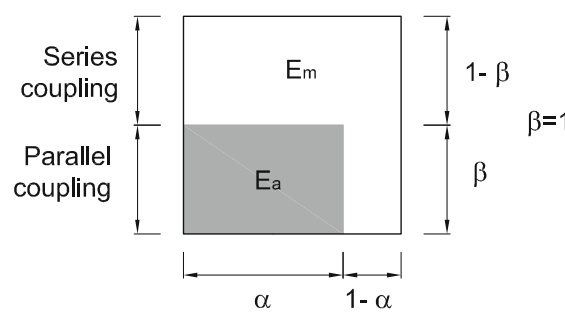

Fig. 3 Schematic representation of the composite model: a volume of aggregate, $\mathrm{V}_{a}$, lower than the maximum compactness of aggregate, $\mathrm{V}_{a, \max }$ considered as a model with a series and

empty spaces are filled with a fluid mortar. In this case the aggregates are in direct contact with each other and, since there is no compaction procedure, no mortar is coupled in series with the aggregates.

The aging viscoelastic behaviour and the continuous stress transfer from the mortar to the stiffer aggregates are modelled using the AAEM method [49] (Eqs. 7-13), described earlier in Sect. 2.3.1, in which the stress-strain behaviour is related the coupled series and parallel two-phase composite model conditions.

The total strain, $\varepsilon\left(t, t^{\prime}\right)$, due to a stress, $\sigma\left(t^{\prime}\right)$, is obtained by the sum of the strain of mortar placed in series, $\varepsilon_{m}\left(t, t^{\prime}\right)$, and the strain of the parallel coupling of mortar and aggregates, $\varepsilon_{a m}\left(t, t^{\prime}\right)$. Considering firstly the strain of the parallel coupling of the composite model, $\varepsilon_{a m}\left(t, t^{\prime}\right)$, the stresses variations in both the mortar, $\Delta \sigma_{m}$, and the aggregates, $\Delta \sigma_{a}$, which yield the stress transfer from the mortar to the aggregates over time, can be obtained by

$$
\begin{aligned}
& \Delta \sigma_{a}\left(t, t^{\prime}\right)=E_{a} \Delta \varepsilon_{p a r}\left(t, t^{\prime}\right) \\
& \Delta \sigma_{m}\left(t, t^{\prime}\right)=E^{\prime \prime}\left(t, t^{\prime}\right)\left[\Delta \varepsilon_{m}\left(t, t^{\prime}\right)-\frac{\sigma_{m}\left(t^{\prime}\right)}{E_{m}\left(t^{\prime}\right)} \phi\left(t, t^{\prime}\right)\right]
\end{aligned}
$$

and the total stress in the mortar is ruled by the parallel model stress-strain relations,

$$
\alpha \Delta \sigma_{a}\left(t, t^{\prime}\right)+(1-\alpha) \Delta \sigma_{m}=0
$$

yielding,

$$
\sigma_{m}\left(t^{\prime}\right)=\sigma\left(t^{\prime}\right) \frac{E_{m}\left(t^{\prime}\right)}{\alpha E_{a}+(1-\alpha) E_{m}\left(t^{\prime}\right)}
$$

Considering an unit stress to obtain the concrete's creep compliance $J\left(t, t^{\prime}\right)$, it is possible to derive the (b) $\mathrm{Va}_{\mathrm{a}}=\mathrm{Va}_{\mathrm{a}} \max (\beta=1)$

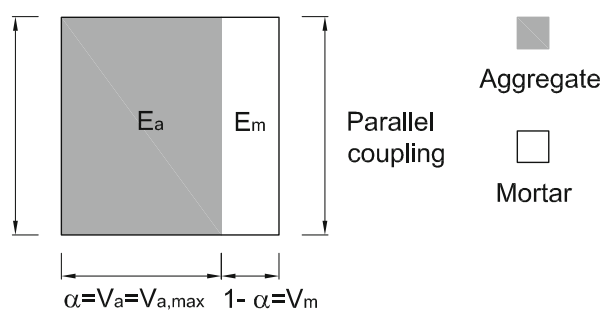

parallel portions; $\mathbf{b}$ volume of aggregate, $\mathrm{V}_{a}$, equal to the maximum compactness of aggregate, $\mathrm{V}_{a, \max }$ yielding a model with parallel coupling

expression for the proposed composite model, taking into account the creep compliance of the mortar placed in series, $J_{m}\left(t, t^{\prime}\right)$.

$$
\begin{aligned}
& J\left(t, t^{\prime}\right)=\frac{\beta}{\alpha E_{a}+(1-\alpha) E_{m}\left(t^{\prime}\right)} \\
& {\left[1+(1-\alpha) \frac{E_{m}^{\prime \prime}}{E_{a m}^{\prime \prime}} \phi\left(t, t^{\prime}\right)\right]+(1-\beta) J_{m}\left(t, t^{\prime}\right)}
\end{aligned}
$$

in which,

$$
\begin{aligned}
& \phi_{m}\left(t, t^{\prime}\right)=E_{m}\left(t^{\prime}\right) J_{m}\left(t, t^{\prime}\right)-1 \\
& E_{m}^{\prime \prime}\left(t, t^{\prime}\right)=\frac{E_{m}\left(t^{\prime}\right)-R_{m}\left(t, t^{\prime}\right)}{\phi_{m}\left(t, t^{\prime}\right)} \\
& E_{a m}^{\prime \prime}\left(t, t^{\prime}\right)=\alpha E_{a}+(1-\alpha) E_{m}^{\prime \prime}\left(t, t^{\prime}\right)
\end{aligned}
$$

where $\phi_{m}\left(t, t^{\prime}\right)$ is the creep coefficient of the mortar, $E_{m}^{\prime \prime}\left(t, t^{\prime}\right)$ is the age-adjusted modulus of elasticity of the mortar and $E_{a m}^{\prime \prime}\left(t, t^{\prime}\right)$ is the age-adjusted modulus of elasticity of the parallel portion of aggregate and mortar.

In conclusion, given the mortar's creep compliance, $J_{m}\left(t, t^{\prime}\right)$, the modulus of elasticity of the inclusions, the fraction volumes of each component and the appropriate parameter $\beta$ is possible to predict the creep compliance of the concrete, $J\left(t, t^{\prime}\right)$, using simple analytical expressions.

\section{Case study}

3.1 Dam characteristics and experimental setup

Baixo Sabor dam, on Sabor river, located in the north eastern Portugal, is a double curvature thick arch dam 
with a height of $123.0 \mathrm{~m}$ and a crest development and thickness of 505.0 and $6.0 \mathrm{~m}$, respectively. Baixo Sabor dam has a total concrete volume of, approximately, $700,000 \mathrm{~m}^{3}$. Due to the large volume placement of concrete, arch dams are usually built using the block construction method [79]. Each of the 32 blocks is, approximately, a $15-\mathrm{m}$ width section of the dam crest development, separated by vertical contraction joints, and cast in 2.0-m height lifts. During construction, the contraction joints were grouted to obtain a monolithic structure, after forced cooling of the concrete blocks. The dam construction began in 2012 and ended in 2014 and the first filling of the reservoir is currently taking place. Figure 4 shows the upstream view of Baixo Sabor dam during the construction.

In order to characterize the deformability properties of dam concrete on site, the National Laboratory for Civil Engineering (LNEC) developed an experimental programme using creep cells (according with the experimental setup described in Sect. 2.2) and laboratory specimens. The in situ experimental setup includes three creep cell sets, placed in three different blocks, CC1, CC2 and CC 3. Each set has three creep cells with three types of concrete: CC 150, cast with dam concrete (or full-mixed concrete); CC \#76, cast with an intermediate wet-screened concrete, \#76 concrete (the aggregates with MSA greater than $76 \mathrm{~mm}$ were removed); and, CC \#38, cast with the usual wet-screened concrete, \#38 concrete (the aggregates with MSA greater than $38 \mathrm{~mm}$ were removed). Due to geometrical and testing equipment limitations, only \#38 wet-screened concrete prismatic specimens

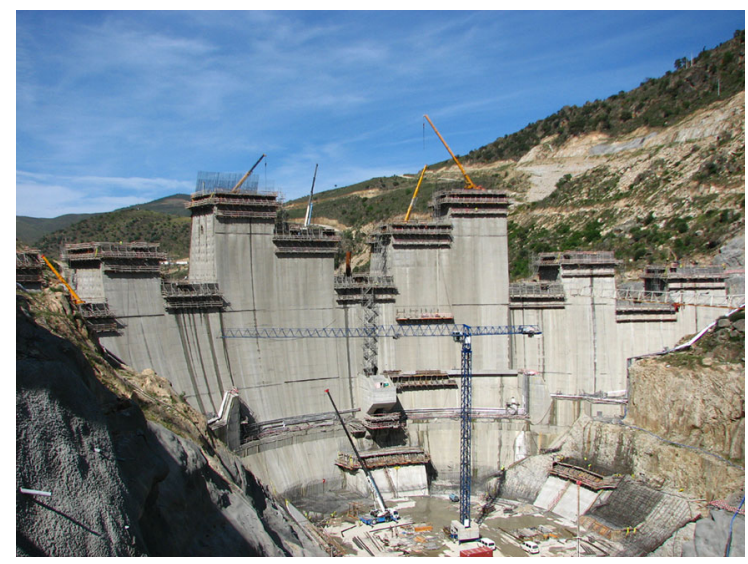

Fig. 4 Baixo Sabor dam during construction were used for laboratory testing ( $\mathrm{P} \# 38$ ). These prismatic specimens were sealed with a lead sheet covering lateral and top faces of the prisms (in order to have no water exchanges with the environment) and maintained with controlled temperature of $20 \pm 1{ }^{\circ} \mathrm{C}$. The laboratory specimens were sealed with wrapped sheet, previously lining the mould, and soldered immediately after casting. Figure 5 shows the three types of specimens used for the in situ experimental installation, considering the MSA of the cast concrete and their respective dimensions, and the prismatic specimen used for laboratory testing. The diameter of the creep cells $(\phi)$ was constrained by the maximum size aggregate of the concrete to be cast and by the flatjack diameter used in the loading system. The ratios $\phi /$ MSA are 3.2 for the dam concrete, 3.9 for the \#76 concrete and 5.9 for the \#38 concrete. Although the recommended minimum ratio for the concrete cell is 4 , the obtained values can be considered admissible for deformability studies $[21,80]$.

\subsection{Concrete composition}

For the design of the dam concrete composition, the temperature control is the main concern whereas the strength is considered to be a secondary requirement [3]. Dam concrete has, therefore, low cement and high fly ash contents, and, since, for the dam core, there is no constraint to the maximum size of the aggregates (MSA), this value can be up to $150 \mathrm{~mm}$, limited by the costs of the processing and batching large aggregates and of the mixing, transporting, placing and consolidation of the concrete [3]. The Baixo Sabor dam concrete were produced with a CEM I 42.5R cement and class F fly ash, according to ASTM C618 and provided by the Compostilla thermoelectric central, in Spain. The coarse aggregates are good quality granite obtained from quarries within the reservoir area.

Table 1 presents the composition of the main dam concrete, with MSA $=150 \mathrm{~mm}$, and an estimate of the compositions of the wet-screened concretes, \#76 and \#38. The water content provided by the aggregate's moisture was obtained considering the moisture percentage of the aggregates $(9.1 \%$ for fine aggregates and $1.4 \%$ for coarse aggregates, average values) and the average water absorption for fine and coarse aggregates $(0.44 \%$ for fine aggregates and $0.6 \%$ for coarse aggregates). Figure 6 shows the particle size distribution of the coarse and fine aggregates of the 
Fig. 5 Creep cells and prismatic specimen dimensions and maximum size of aggregate, MSA, for each concrete

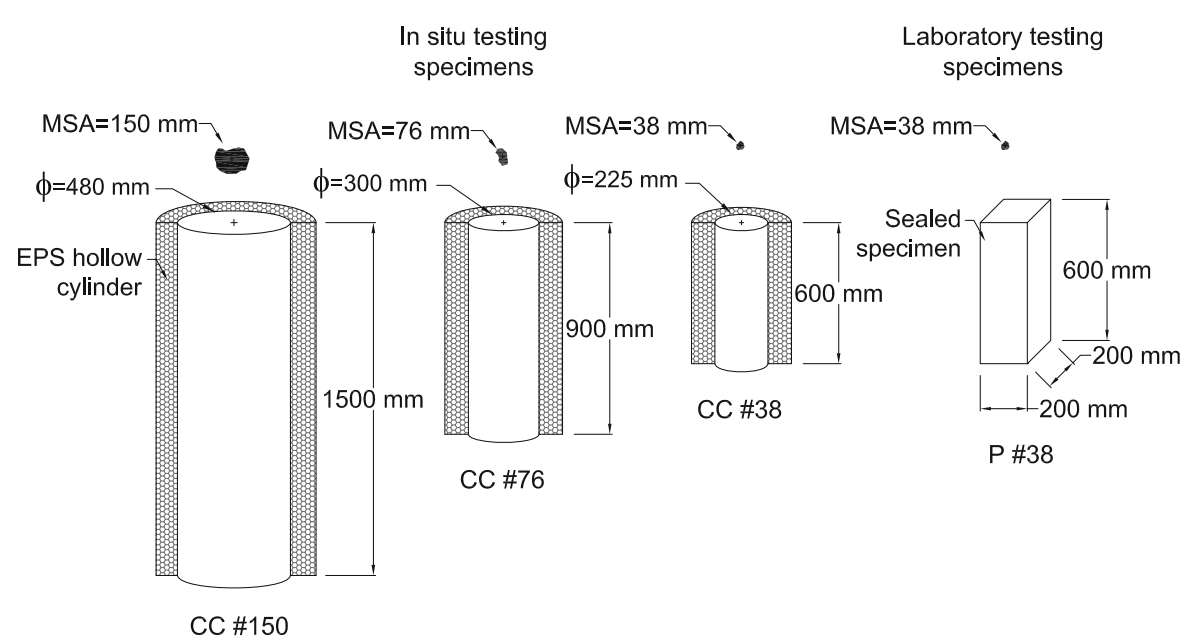

Table 1 Average composition of full-mixed concrete and estimated compositions for \#76 and \#38 mm wet-screened concretes

\begin{tabular}{llllllllll}
\hline Type of concrete & \multicolumn{1}{l}{ Content $\left(\mathrm{kg} / \mathrm{m}^{3}\right)$} & & & & \\
\cline { 2 - 9 } & $c$ & $f$ & $b$ & $w_{\text {add }}$ & $w_{\text {agg }}$ & $w$ & $g$ & $s$ & $a$ \\
\hline Dam & 110.3 & 110.2 & 220.4 & 62.2 & 57.9 & 120.1 & 1441.9 & 556.4 & 1998.3 \\
\#76 (estimated) & 125.6 & 125.3 & 250.8 & 71.3 & 66.3 & 137.6 & 1225.5 & 644.0 & 1869.5 \\
\#38 (estimated) & 143.0 & 142.6 & 285.6 & 83.9 & 78.1 & 162.0 & 988.7 & 710.7 & 1699.4 \\
\hline
\end{tabular}

$c$ cement content, $f$ fly ash content, $b$ binder content, $w_{\text {add }}$ added water content, $w_{\text {agg }}$ content of water in aggregate (moisture), $w$ total water content, $g$ coarse aggregate content, $s$ fine aggregate content, $a$ total aggregate content

concretes used to cast $\mathrm{CC} 1$. The cumulative weight percentages retained in each sieve of the wet-screened concretes are measured values of a sieve analysis after mixing.

The estimate of the \#76 and \#38 concrete compositions was calculated by removing the volume of the

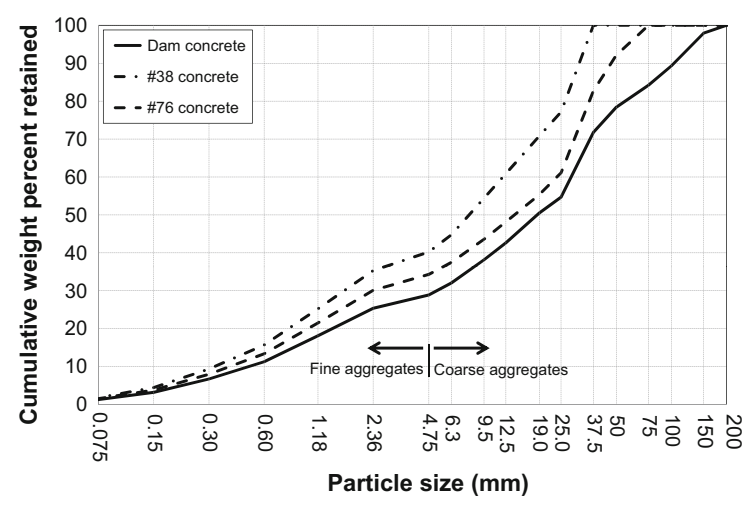

Fig. 6 Sieve analysis of dam concrete, \#76 wet-screened concrete and \#38 wet-screened concrete placed in CC1 sieved coarse aggregate and the volume of the thin layer of mortar that is also removed with those larger aggregates (considering hypothetical spherical aggregates). As the larger aggregates are removed, their volume is replaced with the remaining components and, therefore, wet-screening implies a decrease of coarse aggregate content and an increase of the other components.

\subsection{Compressive creep test results}

Three compression creep tests started at the ages of 28 , 90 and 365 days, for the creep cells sets CC1, CC2 and CC3, respectively. The loading ages were chosen, primarily, to determine the creep behaviour of the dam concrete during the first filling of the reservoir and to evaluate the structural response due to the main loading actions during the lifetime of the dam.

The pressure was maintained constant with the aid of a closed hydraulic system of oil and nitrogen 
(Sect. 2.2). The applied oil pressure was limited to 60 bar to ensure linear and primary creep strains, similar to the dam service conditions, and constraint by the loading capacity of the flat-jacks. The applied stress to the specimen is related to the flat-jack contact area with the creep cell and corresponds to $5.3 \mathrm{MPa}$ for the CC\#150, 5.2 MPa for the CC\#76 and 5.7 MPa for the CC\#38 (Table 2).

Figure 7 shows an example of the compression creep test results obtained for the creep cell cast with full-mixed concrete at the age of 28 days. The measured temperature shows a quick rise until the 3 days of age, followed by a decrease to about $30{ }^{\circ} \mathrm{C}$ at the age of 25 days (Fig. 7a). Due to the subsequent concrete lifts of the block, the temperature in the creep cell was almost constant during a period of 4 months and then it dropped from about $30{ }^{\circ} \mathrm{C}$ to approximately $10{ }^{\circ} \mathrm{C}$ in February 2013 and was kept cool during a long period of time ( 3 months) for the grout filling of the vertical contraction joint. The applied stress (Fig. 7b) was kept approximately constant for the creep test at the age of 28 days, except for the execution of the modulus of elasticity tests, with loading and unloading cycles at predefined ages. Figure $7 \mathrm{c}$ presents the development of the total strains, measured both in the active creep cell and the nonstress creep cell. The main variations are due to temperature and, after 28 days, due to the applied stress in the active cell. Figure 7d) shows the experimental creep compliance calculated for the loading time, since 28 days of age (Eq. 1). The creep compliance increased rapidly in the first days, followed by a decrease in the rate of development until the beginning of the forced cooling, where was measured a small decrease. Figure 8 presents a comparison between the results of each the creep cells at several loading ages.

Table 2 presents a summary of the main results obtained in the creep cells installed in Baixo Sabor dam, for the dam, the \#76 and the \#38 concretes. For each loading age, $t^{\prime}$, and for each type of concrete, the measured temperature at that age, $T\left(t^{\prime}\right)$, the applied stress, $\sigma\left(t^{\prime}\right)$, the modulus os elasticity, $E\left(t^{\prime}\right)$, and the measured creep compliance, $J_{\text {exp }}\left(t, t^{\prime}\right)$, for the time under loading, $t-t^{\prime}$, are shown. Since the temperature on site varies over time, at each loading age the measured temperature was different (approximately $30{ }^{\circ} \mathrm{C}$ for the loading ages of 28 and 90 days and $9.4{ }^{\circ} \mathrm{C}$ for the loading age of 365 days). For the \#38 concrete only the test results for the loading age of 28 days are available, due to a leak on the embedded loading system of both $\mathrm{CC} 2$ and $\mathrm{CC} 3$, detected after installation during testing.

A standard laboratory setup was used to obtain experimental results of delayed deformations under constant environmental conditions for the same concrete batch used for the creep cells. Table 3 presents the experimental results obtained in laboratory for both loading age of 28 and 90 days and for approximately one year under loading (P \#38).

Results show that, concretes wet-screened with lower aperture of the screening sieve give higher creep strains, for every loading ages. This conclusion follows the known behaviour since the wet-screened concrete has a lower content of coarse aggregate and a higher content of cement paste compared with the fullmixed concrete from which it was obtained.

Table 2 Compressive creep test results obtained from creep cells in situ

\begin{tabular}{|c|c|c|c|c|c|c|c|}
\hline $\begin{array}{l}\text { Type of } \\
\text { concrete }\end{array}$ & $\begin{array}{l}\text { Creep } \\
\text { cell }\end{array}$ & $\begin{array}{l}t^{\prime} \\
\text { (days) }\end{array}$ & $\begin{array}{l}t-t^{\prime} \\
\text { (days) }\end{array}$ & $\begin{array}{l}T\left(t^{\prime}\right) \\
\left({ }^{\circ} \mathrm{C}\right)\end{array}$ & $\begin{array}{l}\sigma\left(t-t^{\prime}\right) \\
(\mathrm{MPa})\end{array}$ & $\begin{array}{l}E_{\exp }\left(t^{\prime}\right) \\
(\mathrm{GPa})\end{array}$ & $\begin{array}{l}J_{\exp }\left(t, t^{\prime}\right) \\
\left(10^{-6} / \mathrm{MPa}\right)\end{array}$ \\
\hline \multirow[t]{3}{*}{ Dam } & $\mathrm{CC} 1$ & 27.5 & 362 & 32.3 & 5.3 & 32.5 & 37.2 \\
\hline & $\mathrm{CC} 2$ & 89.0 & 320 & 32.0 & 5.3 & 35.2 & 39.3 \\
\hline & CC3 & 364.4 & 33 & 9.4 & 5.3 & 37.8 & 32.3 \\
\hline \multirow[t]{3}{*}{ \#76 } & $\mathrm{CC} 1$ & 27.8 & 362 & 31.6 & 5.2 & 28.4 & 48.2 \\
\hline & $\mathrm{CC} 2$ & 89.1 & 320 & 30.5 & 5.2 & 31.0 & 39.8 \\
\hline & CC3 & 364.6 & 33 & 9.2 & 5.2 & 32.7 & 38.5 \\
\hline \multirow[t]{3}{*}{ \#38 } & $\mathrm{CC} 1$ & 27.8 & 362 & 31.2 & 5.0 & 25.6 & 62.1 \\
\hline & $\mathrm{CC} 2$ & 90 & 320 & - & - & - & - \\
\hline & CC 3 & 365 & 33 & - & - & - & - \\
\hline
\end{tabular}



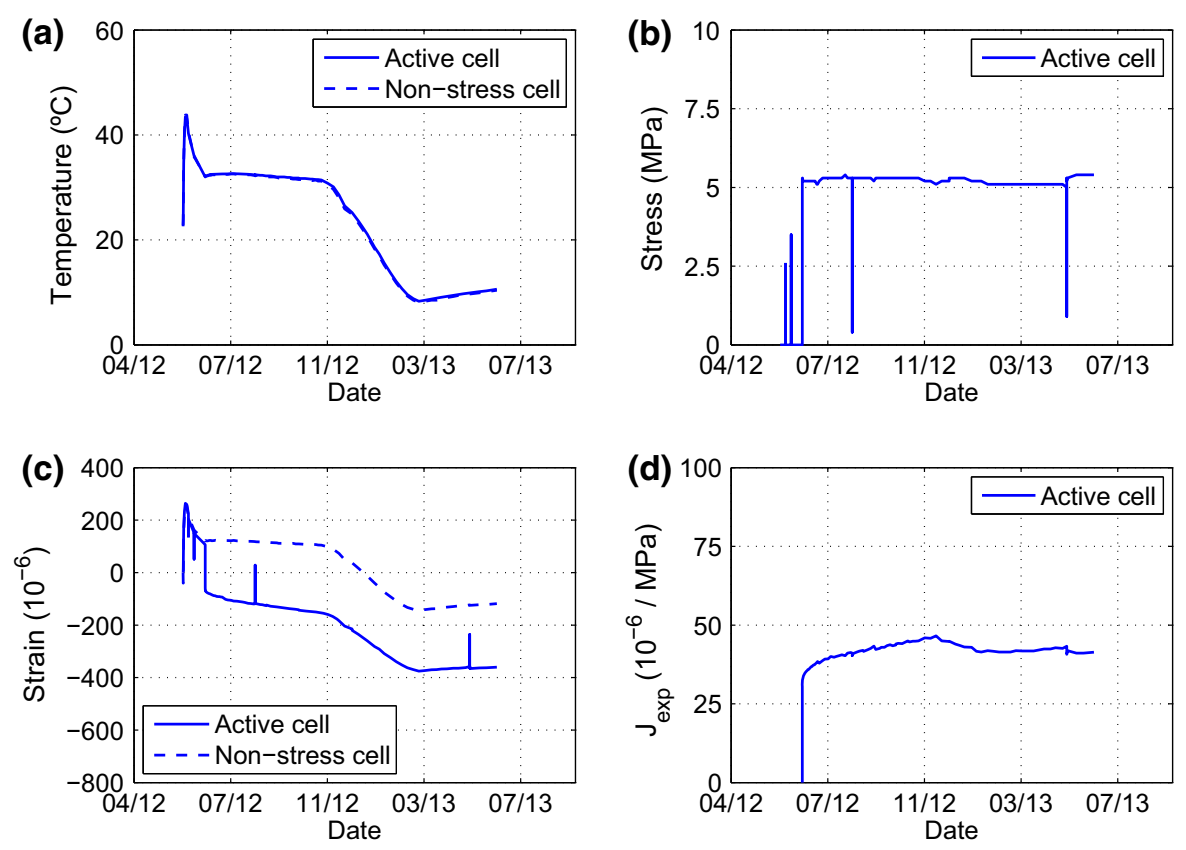

Fig. 7 Compressive creep test results for the creep cell cast with full-mixed concrete at the age of 28 days (CC 150)

The compressive creep test results reveal also the small values of basic creep strains obtained in situ, especially for the full-mixed concrete. The creep strains after one year under loading are only about $20 \%$ of the instantaneous strains at the beginning of the creep test. The experimental work of Sennour, Carrasquilho and Bamforth [81, 82] showed that, the higher the fly ash replacement, lower the creep for moist cured concrete.

The behaviour of wet-screened \#38 mm concrete in situ is similar to the the behaviour of wet-screened \#38 mm concrete tested in laboratory, which despite a lower modulus of elasticity at the loading ages, gives approximately the same creep strains development over time.

\subsection{Prediction of dam concrete creep under compression based on experimental tests of wet-screened concrete}

\subsubsection{Fit to model B3 considering in situ and laboratory conditions}

An optimization procedure based on genetic algorithm (GA) was applied to obtain the parameters $q_{1}, q_{2}, q_{3}$ and $q_{4}$, following the methodology proposed in [56]. The optimization procedure defined constraints for the fitting parameters (only positive values were allowed). The fit considered the data obtained for the three available loading ages, 28, 90 and 365 days, simultaneously. Only the results equally spaced in logarithmic scale were considered in order to ensure a proper weight in the analysed loading time scale. Also, only the periods of time where the temperature was approximately constant were taken into account in the optimization procedure. The choice of the equally spaced values was based on expert judgement, starting with the first available measurement.

The obtained parameters minimize the sum of the square difference between the experimental results, $J_{\text {exp }}\left(t_{T, j}, t_{e, i}^{\prime}\right)$, and the theoretical creep compliance, $J_{B 3}\left(t_{T, j}, t_{e, i}^{\prime}, T_{j}, q_{1}, q_{2}, q_{3}, q_{4}\right)$ (Eq. 39), considering the measured temperature in each creep cell according to the extension of the model B3 to constant elevated temperature (Sect. 2.3.2).

$$
\begin{aligned}
\min & {\left[\sum _ { i = 1 } ^ { m } \sum _ { j = 1 } ^ { n } \left(J_{\exp }\left(t_{T, j}, t_{e, i}^{\prime}\right)\right.\right.} \\
& \left.\left.-J_{B 3}\left(t_{j}, t_{i}^{\prime}, T_{j}, q_{1}, q_{2}, q_{3}, q_{4}\right)\right)^{2}\right]
\end{aligned}
$$

where the $n$ and $m$ are the number of loading ages and the number of measured values over the loading time and $T_{j}$ is the measured temperature. 

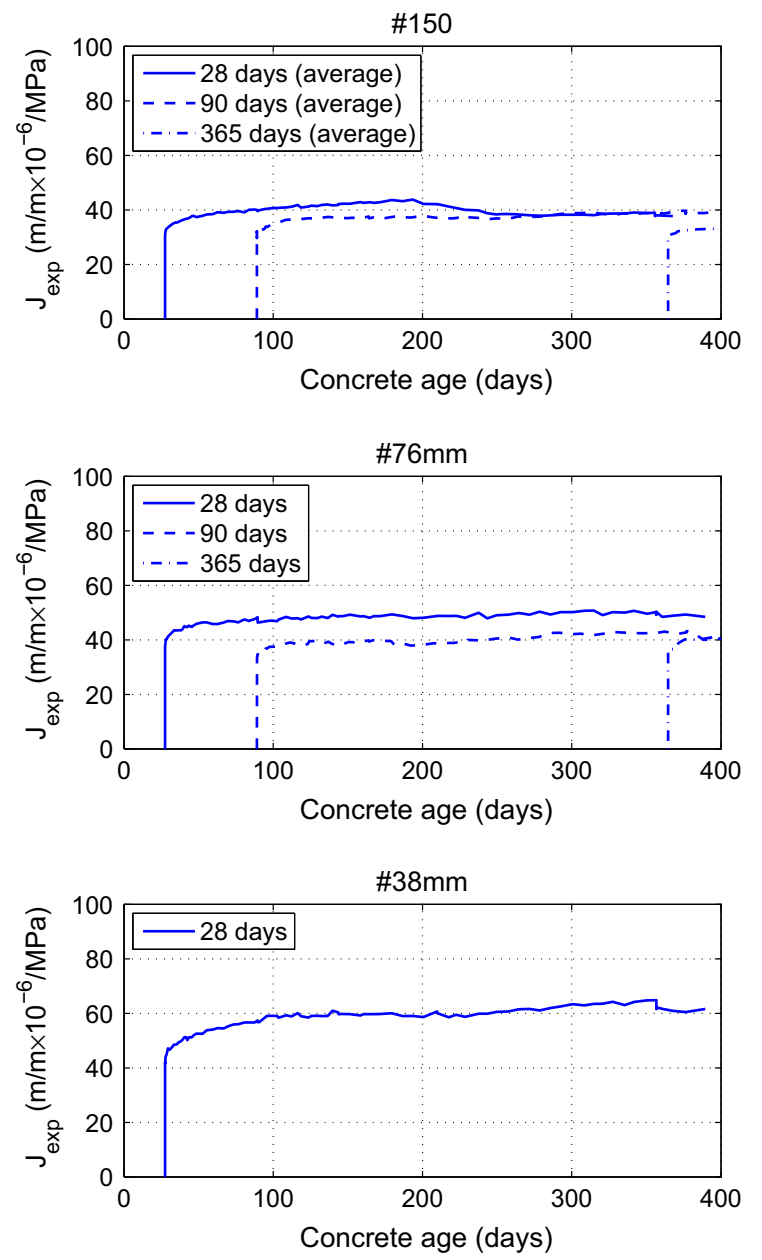

Fig. 8 Experimental compressive creep compliances for the creep cells at several loading ages

The equivalent loading age, $t_{e}^{\prime}$, and the equivalent loading time, $t_{T}-t_{e}^{\prime}$, are calculated using the equivalent age method and the correspondent activation energies, $U_{h} / R, U_{c} / R$ and $U_{c}^{\prime} / R$ (Sect. 2.3.2). An accurate estimate for these activation energies for this concrete is not possible to obtain using the limited experimental results. Some work have been done regarding the development of the strength of concrete with large fly ash content [62, 64, 81-83] but an extensive evaluation of the effect on the activation energies related to creep, $U_{h} / R, U_{c} / R$ and $U_{c}^{\prime} / R$, is still to be done.

The empirical values for $U_{h} / R$ and $U_{c} / R$ were calculated with the average composition data (Table 1) and the strength test results provided from quality control, during construction, for the \#38 concrete: $w=w_{\text {add }}+w_{\text {agg }}=172.2 \mathrm{~kg} / \mathrm{m}^{3}$ and $f_{c, 90}=25.2 \mathrm{MPa}$ (Table 4). At a loading age of 28 days, the compressive creep strains obtained in situ are, in average, $5 \%$ lower than compressive creep strains obtained in laboratory at $20{ }^{\circ} \mathrm{C}$ (Fig. 9, $t^{\prime}$ $=28$ days).

Table 5 presents the parameters and the obtained coefficient of determination, $R^{2}$. The obtained determination coefficients show a good agreement between the updated model and the experimental results. The lower determination coefficients correspond to the optimization of the creep compliance for three loading ages (Dam and \#76 concretes).

Figure 9 shows the in situ (total results and the values used for the optimization process) and the laboratory results, the fit considering the in situ temperatures, $J_{\# 38}\left(t_{T}, t_{e}^{\prime}\right)$, and model B3 creep compliance for the reference temperature $\left(20^{\circ} \mathrm{C}\right)$, using the fitted parameters $q_{1}, q_{2}, q_{3}$ and $q_{4}, J_{\# 38}\left(t, t^{\prime}\right)$.

Figures 10 and 11 show the results and fit obtained for the dam and \#76 concretes, respectively, including the measured in situ creep strains (\#76 (in situ)), the experimental values used for obtaining the model B3 parameters (equally spaced in log-scale), the fitted creep compliance considering the measured temperatures, $J_{\# 76}\left(t_{T}, t_{e}^{\prime}\right)$ and $J_{\text {Dam }}\left(t_{T}, t_{e}^{\prime}\right)$, and the fitted creep compliance for the reference temperature $\left(20{ }^{\circ} \mathrm{C}\right)$, $J_{\# 76}\left(t, t^{\prime}\right)$ and $J_{\text {Dam }}\left(t, t^{\prime}\right)$. The differences between the in situ and laboratory conditions for these types of concretes are less significant, especially for the early loading times, $t-t^{\prime}$.

Table 3 Creep test results obtained from prisms in laboratory

\begin{tabular}{llllllll}
\hline $\begin{array}{l}\text { Type of } \\
\text { concrete }\end{array}$ & $\begin{array}{l}\text { Creep cell } \\
\text { batch }\end{array}$ & $\begin{array}{l}t^{\prime} \\
\text { (days) }\end{array}$ & $\begin{array}{l}t-t^{\prime} \\
(\text { days })\end{array}$ & $\begin{array}{l}T\left(t^{\prime}\right) \\
\left({ }^{\circ} \mathrm{C}\right)\end{array}$ & $\begin{array}{l}\sigma\left(t^{\prime}\right) \\
(\mathrm{MPa})\end{array}$ & $\begin{array}{l}E_{\text {exp }}\left(t^{\prime}\right) \\
(\mathrm{GPa})\end{array}$ & $\begin{array}{l}J_{\text {exp }}\left(t, t^{\prime}\right) \\
\left(10^{-6} / \mathrm{MPa}\right)\end{array}$ \\
\hline$\# 38$ & $\mathrm{CC} 1$ & 27.5 & 362 & 20.3 & 5.7 & 22.1 & 64.2 \\
& $\mathrm{CC} 2$ & 73.5 & 320 & 20.5 & 5.7 & 25.4 & 56.3 \\
\hline
\end{tabular}


Table 4 Coefficients for the extension of model B3 to basic creep at constant elevated temperature

\begin{tabular}{lllllll}
\hline $\begin{array}{l}\text { Type of } \\
\text { concrete }\end{array}$ & $\begin{array}{l}\mathrm{w} \\
\left(\mathrm{kg} / \mathrm{m}^{3}\right)\end{array}$ & $\begin{array}{l}\mathrm{t}^{\prime} \\
(\text { days })\end{array}$ & $\begin{array}{l}f_{c}\left(\mathrm{t}^{\prime}\right) \\
(\mathrm{MPa})\end{array}$ & $\begin{array}{l}U_{h} / R \\
\left({ }^{\circ} \mathrm{K}\right)\end{array}$ & $\begin{array}{l}U_{c} / R \\
\left({ }^{\circ} \mathrm{K}\right)\end{array}$ & $U_{c}^{\prime} / R$ \\
\hline Dam & 120.1 & 90 & 24.7 & 5000 & 5300.9 & 954.2 \\
$\# 76$ & 137.6 & 90 & $24.7^{*}$ & & 5109.8 & 919.8 \\
$\# 38$ & 162.0 & 90 & 25.2 & & 4942.6 & 889.7 \\
\hline
\end{tabular}

* The compressive strength of \#76 concrete was considered to be the same as dam concrete

The obtained creep strains for each concrete show a decrease of rate of development for later loading ages, due to aging, and for larger coarse aggregate contents. The aggregates restraint the development of the creep strains over time, due to a transfer of stress from the mortar to the aggregate skeleton.

\subsubsection{Prediction of the full-mixed concrete creep under compression using composite models}

Dam concrete has large size aggregates which constraints the use of standard testing procedures and the dimensions of the instrumentation. Due to high costs and several testing difficulties, dam concrete is poorly characterized, especially concerning its delayed behaviour. The wet-screened concrete is widely used for concrete quality control, concrete mechanical characterization and to embed specific instrumentation devices.

The proposed prediction of dam concrete creep under compression is based on the experimental results of wet-screened concrete measured in situ. The methodology relies, firstly, on the equivalence between in situ and laboratory results, described in Sect. 3.4.1 to take into account the elevated constant temperature measured in situ. Secondly, it is proposed the use of the composite model theory (Sect. 2.3.3) to predict the effects of the changes on composition, in particular, the variations of coarse aggregate content.

The composite model described in Sect. 2.3.3 was adapted to consider dam concrete a composite material where the wet-screened concrete works as an equivalent matrix and the remaining aggregate as the inclusions. Two composite models, Composite \#76-
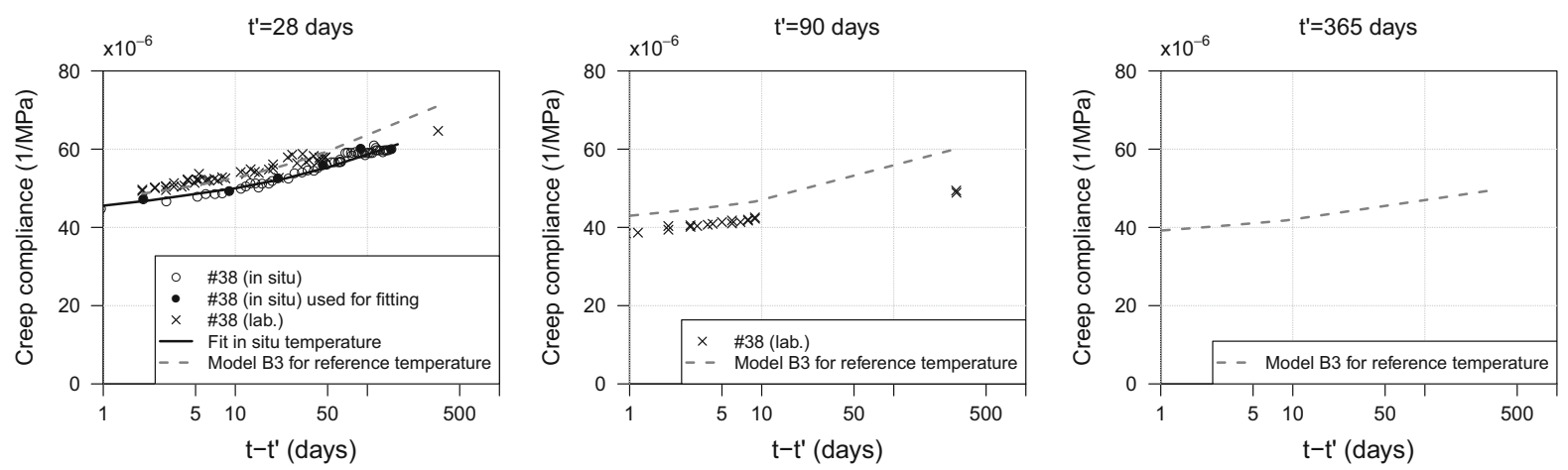

Fig. 9 Compressive creep test results of \#38 concrete at several ages and fit to model B3 for elevated constant temperature (in situ conditions) and constant reference temperature conditions

Table 5 Equivalent age and equivalent loading time used in the analysis and the parameters obtained by the optimization procedure

\begin{tabular}{|c|c|c|c|c|c|c|c|c|c|c|c|}
\hline $\begin{array}{l}\text { Type of } \\
\text { concrete }\end{array}$ & $\begin{array}{l}\text { Creep } \\
\text { Cell }\end{array}$ & $\begin{array}{l}t^{\prime} \\
\text { (days) }\end{array}$ & $\begin{array}{l}t-t^{\prime} \\
\text { (days) }\end{array}$ & $\begin{array}{l}t_{e}^{\prime} \\
\text { (days) }\end{array}$ & $\begin{array}{l}t_{T}-t_{e}^{\prime} \\
\text { (days) }\end{array}$ & $\begin{array}{l}\text { Creep } \\
\text { compliance }\end{array}$ & $\begin{array}{l}q_{1} \\
\left(10^{-6} / \mathrm{MPa}\right)\end{array}$ & $\begin{array}{l}q_{2} \\
\left(10^{-6} / \mathrm{MPa}\right)\end{array}$ & $\begin{array}{l}q_{3} \\
\left(10^{-6} / \mathrm{MPa}\right)\end{array}$ & $\begin{array}{l}q_{4} \\
\left(10^{-6} / \mathrm{MPa}\right)\end{array}$ & $\begin{array}{l}R^{2} \\
(-)\end{array}$ \\
\hline \multirow[t]{3}{*}{ Dam } & $\mathrm{CC} 1$ & 27.5 & 159.1 & 65.6 & 182.8 & $J_{\text {Dam }}\left(t, t^{\prime}\right)$ & 26.47 & 13.87 & 8.21 & 5.87 & 0.837 \\
\hline & $\mathrm{CC} 2$ & 89.0 & 83.0 & 215.8 & 93.8 & & & & & & \\
\hline & CC3 & 364.4 & 33.0 & 505.2 & 29.1 & & & & & & \\
\hline \multirow[t]{3}{*}{ \#76 } & $\mathrm{CC} 1$ & 27.8 & 152.0 & 66.6 & 185.8 & $J_{\# 76}\left(t, t^{\prime}\right)$ & 30.40 & 60.16 & 4.61 & 4.89 & 0.796 \\
\hline & $\mathrm{CC} 2$ & 89.1 & 56.9 & 205.5 & 67.4 & & & & & & \\
\hline & CC3 & 364.6 & 33.0 & 502.2 & 27.2 & & & & & & \\
\hline \#38 & $\mathrm{CC} 1$ & 27.8 & 152.0 & 64.1 & 169.8 & $J_{\# 38}\left(t, t^{\prime}\right)$ & 24.17 & 82.75 & 17.40 & 5.54 & 0.986 \\
\hline
\end{tabular}



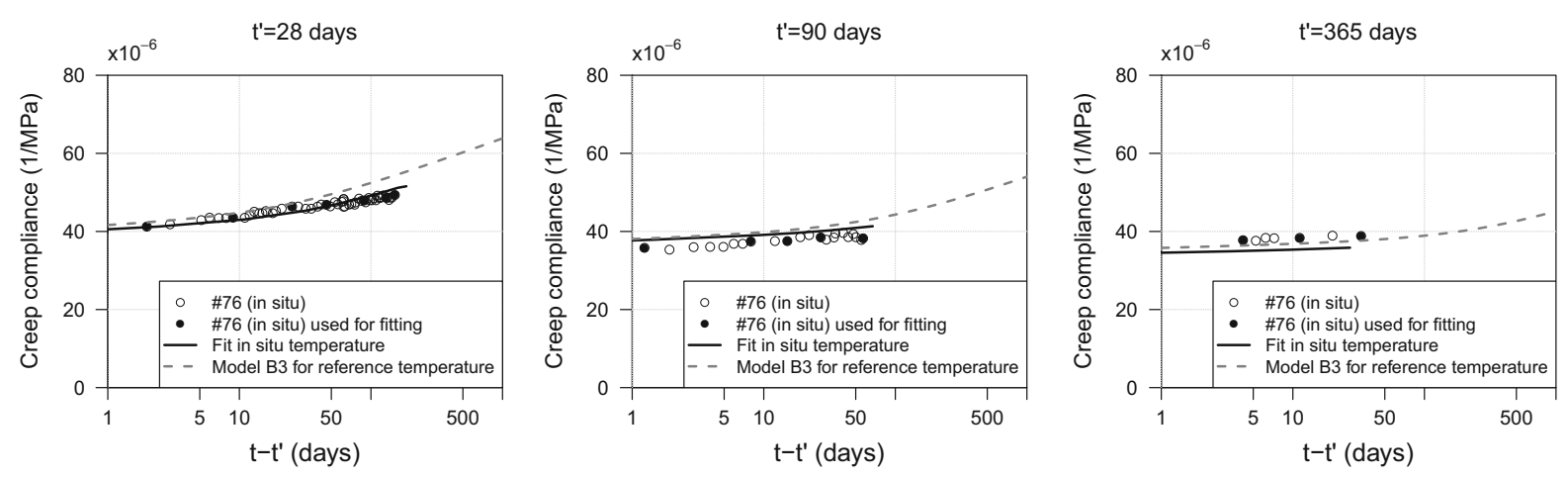

Fig. 10 Compressive creep test results of \#76 concrete at several ages and fit to model B3 for elevated constant temperature (in situ conditions) and constant reference temperature conditions
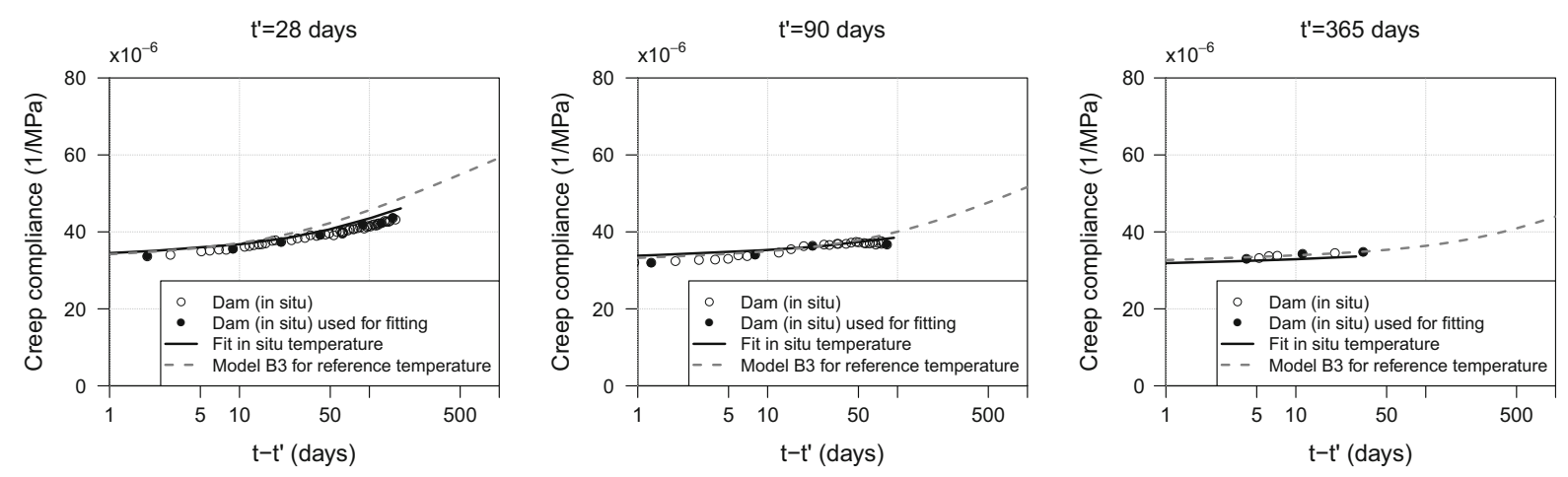

Fig. 11 Compressive creep test results of dam concrete at several ages and fit to model B3 for elevated constant temperature (in situ conditions) and constant reference temperature conditions

Dam and Composite \#38-Dam, were considered. The compressive creep test results of both types of wetscreened concrete, $J_{\# 76}\left(t, t^{\prime}\right)$ and $J_{\# 38}\left(t, t^{\prime}\right)$, its fraction volumes with respect to the volume of the dam concrete, $V_{\# 76}$ and $V_{\# 38}$, the modulus of elasticity of the removed aggregate, $E_{a}$, and the fraction volumes of the removed aggregate, $V_{a}>76 \mathrm{~mm}$ and $V_{a}>38 \mathrm{~mm}$, were considered. An additional composite model, Composite \#38-\#76, was used to validate the application of the proposed methodology (Table 6). Table 6 summarizes the properties used in the equivalent composite model analysis.

The wet-screening procedure implies a change in the matrix composition since some mortar is removed with the larger aggregates (Table 1). This mortar is considered to be a very small portion of volume when compared with the equivalent matrix (considered, in this case, to be the wet-screened concrete).
Figure 12 shows a representation of the considered composite models (Composite \#76-Dam, Composite \#38-Dam and Composite \#38-\#76), and the involved different parameters $\left(\alpha_{\# 76-D a m}, \beta_{\# 76-\text { Dam }}\right.$, $\alpha_{\# 38-D a m}, \beta_{\# 38-D a m}, \alpha_{\# 38-\# 76}$ and $\left.\beta_{\# 38-\# 76}\right)$. For the Composite \#76-Dam the volume fraction of the wetscreened aggregates is lower than for the Composite \#38-Dam (Table 6) and, therefore, the involved parameters can be different for each case.

Firstly, the procedure described in Sect. 3.4.1 leads to the creep compliance under compression at a reference constant temperature, $J_{\text {Dam }}\left(t, t^{\prime}\right), J_{\# 76}\left(t, t^{\prime}\right)$ and $J_{\# 38}\left(t, t^{\prime}\right)$. Therefore, the comparison of the results for each type of concrete, dam, \#76 and \#38 concretes, independently from the maturing conditions, was possible. Considering the composition data and the creep compliance under compression of both wetscreened concretes for reference temperatures, 
Table 6 Properties used for the equivalent composite model analysis

\begin{tabular}{llllc}
\hline $\begin{array}{l}\text { Composite } \\
\text { model }\end{array}$ & $\begin{array}{l}\text { Creep compliance of } \\
\text { equiv. matrix }\left(10^{-6} / \mathrm{MPa}\right)\end{array}$ & $\begin{array}{l}E_{a} \\
(\mathrm{GPa})\end{array}$ & $\begin{array}{l}\mathrm{V}_{\text {eq.matrix }}= \\
\mathrm{V}_{\text {wet-scr. concrete }}\end{array}$ & $\mathrm{V}_{a>M S A}$ \\
\hline$\# 76-$ Dam & $\mathrm{J}_{\# 76}$ (Table 5) & 46.3 & 0.86 & 0.14 \\
$\# 38-D a m$ & $\mathrm{~J}_{\# 38}$ (Table 5) & & 0.72 & 0.28 \\
$\# 38-\# 76$ & $\mathrm{~J}_{\# 38}$ (Table 5) & & 0.84 & 0.16 \\
\hline
\end{tabular}

Fig. 12 Adapted composite model for wet-screening procedure

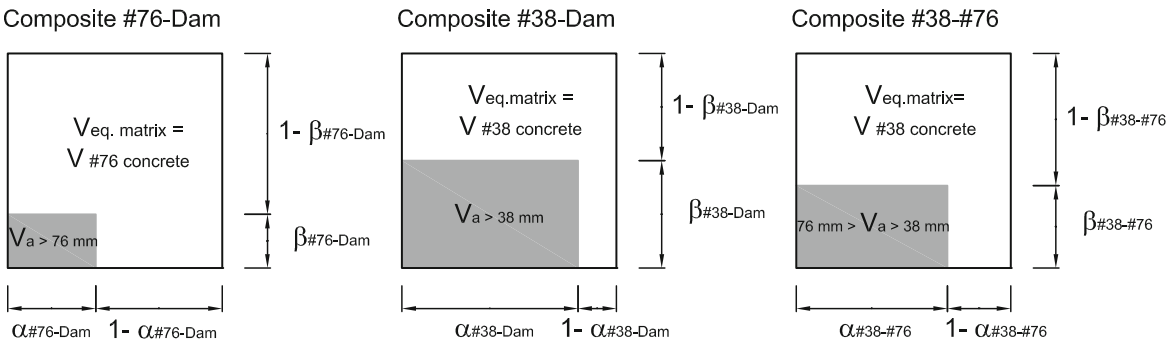

$J_{\# 76}\left(t, t^{\prime}\right)$ and $J_{\# 38}\left(t, t^{\prime}\right)$, the equivalent composite model was used to predict the compressive creep compliance of dam concrete, $J_{\text {composite }}^{\beta}\left(t, t^{\prime}\right)$ and compared with $J_{\text {Dam }}\left(t, t^{\prime}\right)$.

The optimum $\beta$ was obtained by calculating the percentage difference, $\% \Delta_{\text {composite }}^{\beta}$, between the composite prediction and the experimental result for the range of possible $\beta$, varying from 0.1 to 1.0. The percentage different, $\% \Delta_{\text {composite }}^{\beta}$, represents the average relative error of a prediction and was calculated using the range of available loading times for each composite model, $n$.

$\% \Delta_{\text {composite }}^{\beta}\left(t^{\prime}\right)=\frac{\sum_{j=1}^{n} \frac{\left|J_{\text {composite }}^{\beta}\left(t_{j}, t^{\prime}\right)-J_{150}\left(t_{j}, t^{\prime}\right)\right|}{J_{150}\left(t_{j}, t^{\prime}\right)}}{n}$

The influence of the composite model free parameters, $\beta_{\# 76-D a m}, \beta_{\# 38-D a m}$ and $\beta_{\# 38-\# 76}$ on the obtained predictions of dam concrete is presented in Fig. 13. (Eq. 40).

The percentage difference for the three loading ages, varies significantly with $\beta$. The $\beta$ value with the lowest value of $\% \Delta_{\text {composite }}^{\beta}$ corresponds to the prediction model to be used. For the Composite \#76-Dam and the Composite \#38-\#76, the value of $\beta$ that gives the best fit for the three loading ages are, $\beta=0.4$ and $\beta=0.3$, respectively (Fig. 14). The Composite \#38Dam has its lowest percentage difference for a $\beta=0.6$. The existence of a minimum for almost every loading age and for the validation example (Composite \#38-\#76), shows the consistency of the proposed methodology and that the model is able to accurately predict the composite creep strains, for a given $\beta$.

Considering the average differences of the available loading ages, the results show a better agreement for a low value of $\beta$ for the composite model using the \#76 composite model and for a higher value of $\beta$ for the \#38 composite model (Fig. 13). The higher the $\beta$, the least is the volume of matrix that is coupled in series with the aggregates. The Composite \#76-Dam has, therefore, more equivalent matrix placed in series with the inclusions than the Composite \#38-Dam due to the small amount of inclusions, $V_{a}>76 \mathrm{~mm}$, and due to the fact that the larger aggregates (MSA $>76 \mathrm{~mm}$ ) are sparser in the wet-screened concrete matrix.

Figures 14, 15 and 16 show the development of the creep strains of the wet-screened concrete (grey solid lines) and the dam concrete (black dashed lines) and the dam concrete prediction using the respective composite model (black solid lines).Please check and confirm the inserted citation of Fig. 16 is correct. If not, please suggest an alternative citation. Please note that Figure should be cited in ascending numerical order in the text. and should be inside the main body of the text.The inserted citation of Fig. 16 is correct. Thank you.

It can be concluded that the predictions of dam concrete creep strains are good, given the complexity of the phenomena and the limited test results. The higher deviations occur for the Composite \#38-Dam at the loading age of 28 days and for the early ages after loading. These deviations can be due to limited compressive creep 

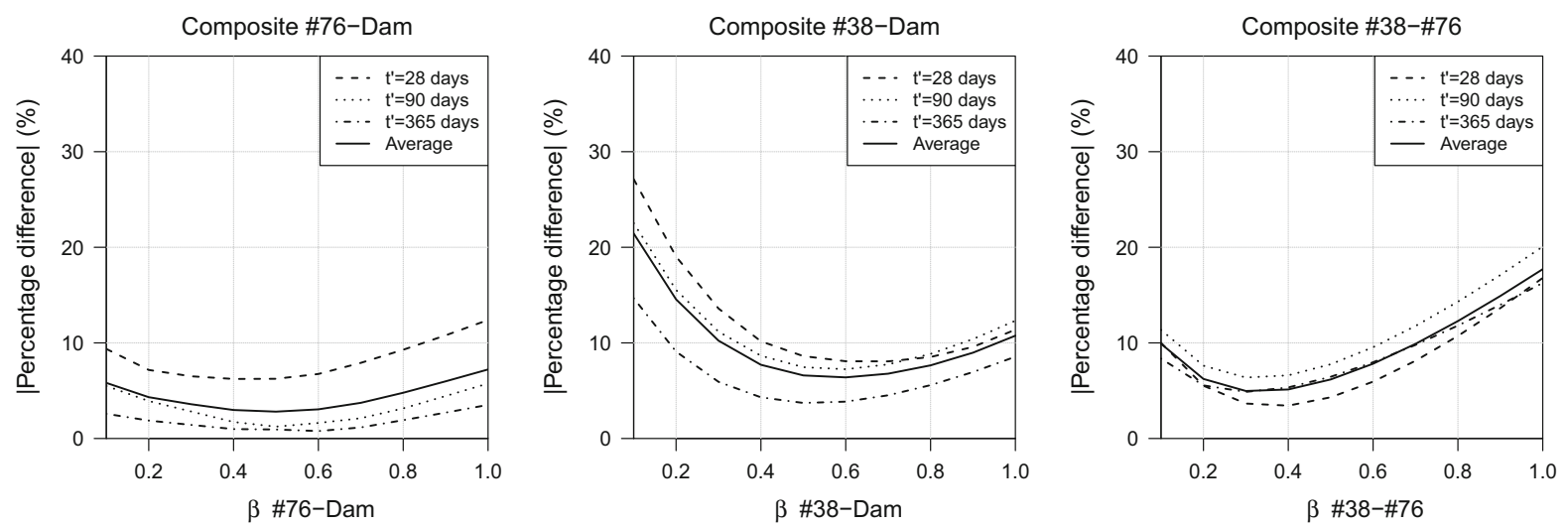

Fig. 13 Percentage difference between the prediction using the equivalent composite and the experimental results for several values of $\beta$
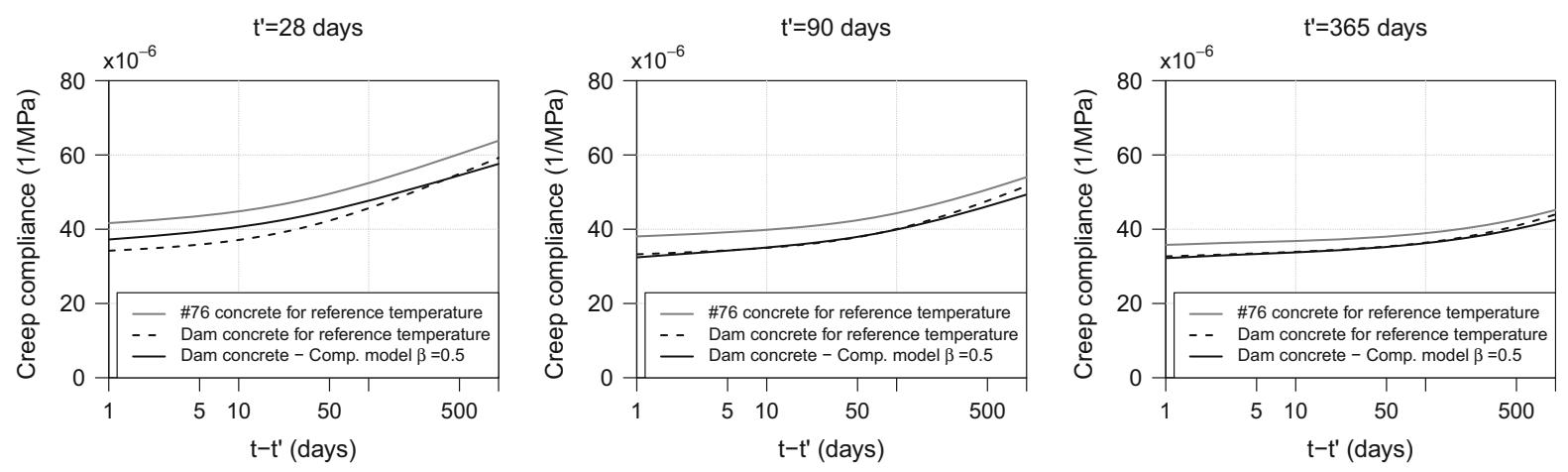

Fig. 14 Prediction of full-mixed concrete creep compliance under compression using \#76 mm equivalent composite model $(\beta=0.5)$
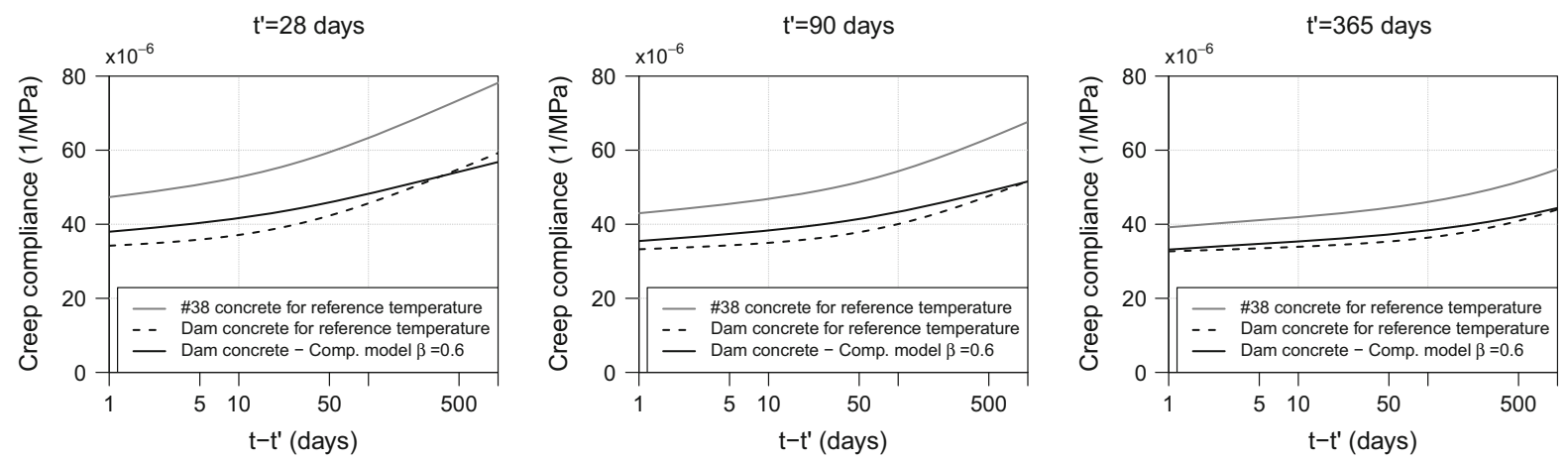

Fig. 15 Prediction of full-mixed concrete creep compliance under compression using \#38 mm equivalent composite model $(\beta=0.6)$

strain results and its implications on the optimization procedures to fit the model B3 parameters.

The $\beta$ values are related to the amount of equivalent matrix placed parallel in the composite model and can be related to the maximum amount of aggregate, $V_{a, \max }$. The maximum amount of aggregate in the composite model is obtained for $\beta=1.0$. According to the theoretical Caquot law, the maximum amount of aggregate can be given by,

$$
V_{a, \max }=1-0.47\left(\frac{d_{\min }}{d_{\max }}\right)^{\frac{1}{5}}
$$



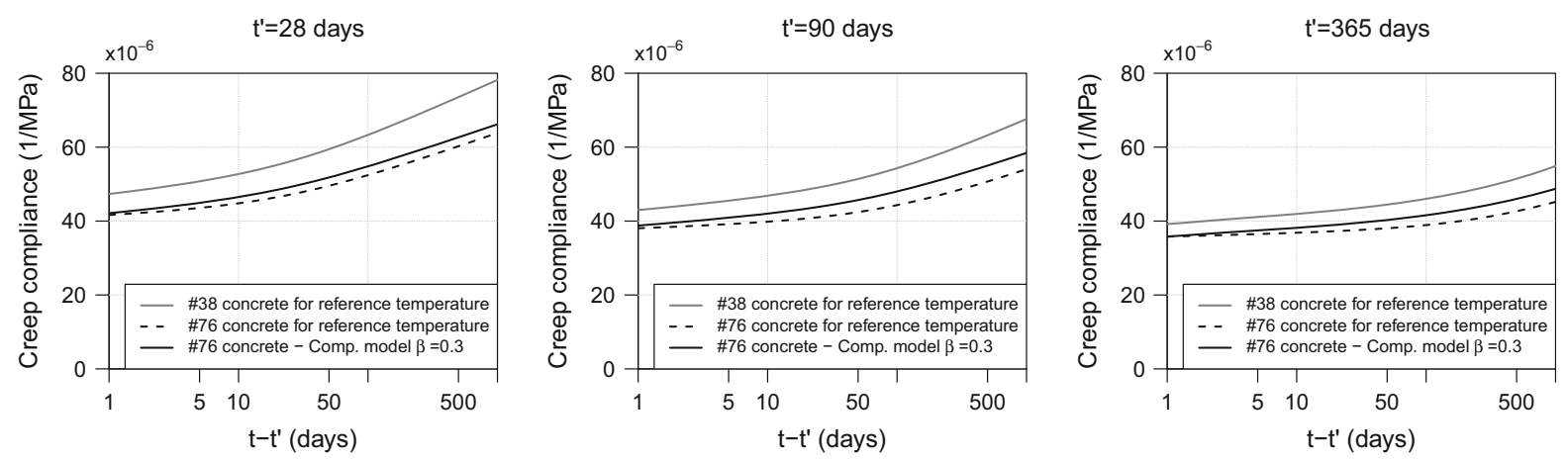

Fig. 16 Prediction of \#76 concrete creep compliance under compression using \#38 mm equivalent composite model ( $\beta=0.3$ )

where $d_{\min }$ and $d_{\max }$ are the minimum and maximum size of the aggregates. This estimate can be used to compare the obtained $\beta_{\text {Caquot }}$ coefficients for each composite, given the hypothesis of the equivalent composite model (Table 7).

Although the $\beta$ estimates are lower than the ones obtained by the optimization of the percentage difference to the experimental results, the relationship between them are consistent.

\section{Conclusions}

The rheological properties of dam concrete are different from the derived wet-screened concrete, both for instantaneous behaviour and delayed behaviour. As a result of its specific use, studies involving dam concrete are sparse and locally significant. Comprehensive experimental programmes are needed for understanding the influence of high content of large coarse aggregate on the mechanical properties of this type of material. In this particular case, analytical models, such as composite models, are an important tool for a first approach to the structural design and safety control assessment.

The first part of this work describes the experimental study concerning the behaviour of dam and wet-

Table 7 Comparison between estimate of $\beta$ given by Caquot law and the by the fit to the experimental results

\begin{tabular}{llllll}
\hline $\begin{array}{l}\text { Composite } \\
\text { model }\end{array}$ & $\begin{array}{l}d_{\min } \\
(\mathrm{mm})\end{array}$ & $\begin{array}{l}d_{\max } \\
(\mathrm{mm})\end{array}$ & $V_{a, \max }$ & $\beta_{\text {Caquot }}=V_{a} / V_{a, \max }$ & $\beta_{\mathrm{fit}}$ \\
\hline \#76-Dam & 76 & 150 & 0.59 & 0.27 & 0.5 \\
\#38-Dam & 38 & 150 & 0.64 & 0.44 & 0.6 \\
$\# 38-\# 76$ & 38 & 76 & 0.59 & 0.27 & 0.3 \\
\hline
\end{tabular}

screened concrete for the dam core conditions. An in situ experimental apparatus was used in order to measure the compressive creep strains development over time, for three loading ages and for the three types of concrete.

It is proposed a methodology for the prediction of the dam concrete delayed deformability properties based on the experimental in situ results of the wetscreened concrete. The compressive creep compliance was fitted for a reference temperature state, using the measured creep strains of each concrete. Then, an equivalent two-phase composite model was applied considering the dam concrete as a composite material of wet-screened concrete (viscoelastic matrix) and the removed larger aggregates after sieving (elastic inclusions).

The comparison between the dam concrete compressive creep strains prediction and the obtained experimental results, at reference temperature conditions, show an overall good agreement. The main deviations between the predictions and the measurement seem to be related to the fit to experimental results to the model $\mathrm{B} 3$ at a large range of loading ages and loading durations and to the different compaction conditions related to the two types of wet-screened concrete. A sensitivity analysis was made, using the composite model parameter $\beta$, related to the aggregate compaction conditions of the concrete, to obtain a good agreement with the experimental results of dam concrete and the optimum composite model parameters.

The further understanding of the relationship between dam and wet-screened concrete creep in compression and the development of prediction models will contribute towards the improvement of design guidelines and of monitoring and safety control 
practices, regarding the assessment of long-term lifetime deterioration scenarios.

Acknowledgments Thanks are due to EDP-Energias de Portugal for permission to publish data relative to Baixo Sabor dam and to the National Laboratory for Civil Engineering for supporting the developed work.

\section{References}

1. U.S.B.R. (1988) Concrete manual: a water resources technical publication, 8th edn. United States Government Printing Office, Washington

2. ICOLD (2008) ICOLD Bulletin: the physical properties of hardened conventional concrete in dams. Draft for ICOLD review. Tech rep, March, ICOLD

3. ACI Committee 207 (2005) 207.1R-05: guide to mass concrete. Tech rep, American Concrete Institute, Detroit

4. Noorzaei J, Bayagoob K, Thanoon W, Jaafar M (2006) Thermal and stress analysis of Kinta RCC dam. Eng Struct 28(13):1795-1802. doi:10.1016/j.engstruct.2006.03.027

5. Cervera M, Oliver J, Prato T (2000) Thermo-chemo-mechanical model for concrete. I: hydration and aging. J Struct Eng 126(9):1053. doi:10.1061/(ASCE)0733-9445(2000) 126:9(1053)

6. Cervera M, Oliver J, Prato T (2000) Simulation of construction of RCC dams. II: Stress and damage. J Struct Eng 126(9):1062-1069. doi:10.1061/(ASCE)0733-9445(2000) 126:9(1062)

7. Schrefler BA, Pesavento F, Sanavia L, Sciume G, Secchi S, Simoni L (2010) A general framework for modeling longterm behavior of earth and concrete dams. Front Archit Civ Eng China 5(1):41-52. doi:10.1007/s11709-010-0070-x

8. Charlwood R (2009) Predicting the long term behaviour and service life of concrete dams. In: 2nd Int Conf Long term Behav dams, Graz

9. Naus DJ, Johnston MW (2001) International RILEM workshop on life prediction and aging management of concrete structures. Mater Struct 34(8):458-466. doi:10. 1007/BF02486493

10. Jia J (2010) Several issues to be considered for long-term better behavior of concrete gravity dams. Front Archit Civ Eng China 4(1):40-46. doi:10.1007/s11709-010-0006-5

11. NP EN 206 (2005) NP EN 206-1: especificação, desempenho, produção e conformidade. Tech rep, Instituto Português da Qualidade, Lisboa

12. Popovics S, Ujhelyi J (2008) Contribution to the concrete strength versus water-cement ratio relationship. J Mater Civ Eng 20(7):459-463. doi:10.1061/(ASCE)0899-1561(2008)20:7(459)

13. Elices M, Rocco C (2008) Effect of aggregate size on the fracture and mechanical properties of a simple concrete. Eng Fract Mech 75(13):3839-3851. doi:10.1016/j. engfracmech.2008.02.011

14. Vilardell J, Aguado A, Agullo L, Gettu R (1998) Estimation of the modulus of elasticity for dam concrete. Cem Concr Res 28(1):93-101

15. Topçu IB, Ugurlu A (2007) Elasticity theory of concrete and prediction of static E-modulus for dam concrete using composite models. Tek Dergi 18(1):4055-4067
16. Khaloo AR, Mohamadi Shooreh MR, Askari SM (2009) Size influence of specimens and maximum aggregate on dam concrete: compressive strength. J Mater Civ Eng 21(8):349-355. doi:10.1061/(ASCE)0899-1561(2009)21: $8(349)$

17. Deng Z, Li Q, Fu H (2008) Comparison between mechanical properties of dam and sieved concretes. J Mater Civ Eng 20(4):321-326. doi:10.1061/(ASCE)0899-1561(2008)20: 4(321)

18. CEB-FIP (2010) Model Code 2010

19. ACI Committee 209 (1992) 209R-92: prediction of creep, shrinkage, and temperature effects in concrete structures (Reapproved 2008). Tech rep, American Concrete Institute, Detroit

20. Popovics S (1982) Strength relationships for fly ash concrete. J Proc 79(1):43-49

21. Neville A, Dilger W, Brooks J (1983) Creep of plain and structural concrete. Longman Inc., New York

22. Coutinho A (1977) A contribution to the mechanism of concrete creep. Matériaux Constr. 10(1):3-16. doi:10.1007/ BF02473583

23. Acker P (2001) Creep and shrinkage of concrete: physical origins and practical measurements. Nucl Eng Des 203(2-3):143-158. doi:10.1016/S0029-5493(00)00304-6

24. Vandamme M, Ulm F (2009) Nanogranular origin of concrete creep. Proc Natl Acad Sci USA 106(26):10552-10557. doi:10.1073/pnas.0901033106

25. Bažant, ZP (1975) Theory of creep and shrinkage in concrete structures: a précis of recent development. In: Mechanical today, Vol. 2, Pergamon Press, pp 1-93

26. Bažant ZP (1982) Mathematical models for creep and shrinkage of concrete. In: Bažant ZP, Wittmann FH (eds) Creep and shrinkage of concrete strucuture. chap. 7, Wiley, London, pp. 163-256

27. Bažant ZP (ed) (1988) Material models for structural creep analysis. In: Mathematical modeling creep shrinkage concrete. chap. 2, Wiley, Evanston, pp 99-215

28. Bažant ZP, Baweja S (1995) Creep and shrinkage prediction model for analysis and design of concrete structures - model B3. Mater Struct 28:357-365

29. Bažant ZP, Baweja P (2000) Creep and shrinkage prediction model for analysis and design of concrete structures - model B3. In: Al-Manaseer A (ed) Adam neville symposium: creep and shrinkage-structural design effects, vol. 28, Michigan, pp. 1-83. doi:10.1007/BF02473152

30. Ghosh RS, Timusk J (1981) Creep of fly ash concrete. ACI J. 78(5):351-357

31. Kogan EA (1991) Creep of roller-compacted concrete. Hydrotech Constr 25(3):147-152. doi:10.1007/BF0142 3977

32. Smith DM, Hammons MI (1993) Creep of mass concrete at early ages. J Mater Civ Eng 5(3):411-417

33. Padevět P, Bittnar P (2013) The creep of cement paste with various content of fly ash in the age 1 year. In: Mladenov V, Kralov I, Tashev T, Popescu F, López JIH, Kattel G, Martins AMT (eds) Recent advance continuous mechnical hydrology ecology. WSEAS Press, Rhodes Island, Greece, pp 20-24

34. Rilem TC 107-GCS (1995) Creep and shrinkage prediction model for analysis and design of concrete structures - model B3. Mater Struct 28(180):357-365 
35. Carino NJ, Lew HS (2001) The maturity method: from theory to application. In: Chang P (ed) Structure congress exposition. American Society of Civil Engineers, Washington D. C., p 19

36. Zhang J, Cusson D, Monteiro P, Harvey J (2008) New perspectives on maturity method and approach for high performance concrete applications. Cem Concr Res 38(12):1438-1446

37. Bažant ZP, Osman E (1976) Double power law for basic creep of concrete. Mater Struct (RILEM, Paris) 9(49):3-11

38. Popovics S (1986) Effect of curing method and final moisture condition on compressive strength of concrete. J Proc 83(4):650-657

39. Bažant ZP, Hauggaard A, Baweja S, Ulm F (1997) Microprestress-solidification theory for concrete creep. I: aging and drying effects. J Eng Mech 123(11):1188. doi:10.1061/ (ASCE)0733-9399(1997)123:11(1188)

40. Hashin Z (1962) The elastic moduli of heterogeneous materials. J Appl Mech 29(1):143. doi:10.1115/1.3636446

41. Hansen T (1965) Influence of aggregate and voids on modulus of elasticity of concrete, cement mortar, and cement paste. ACI J 62(2):193-216

42. Hirsch TJ (1962) Modulus of elasticity of concrete affected by elastic moduli of cement paste matrix and aggregate. J Proc 59(3):427-452

43. Counto UJ (1964) The effect of the elastic modulus of the aggregate on the elastic modulus, creep and creep recovery of concrete. Mag Concr Res 16(48):129-138. doi:10.1680/ macr.1964.16.48.129

44. Topçu IB (2005) Alternative estimation of the modulus of elasticity for dam concrete. Cem Concr Res 35(11):2199-2202. doi:10.1016/j.cemconres.2004.08.010

45. Neville AM, Ward MA, Kwei GCS (1969) Basic and drying creep of concrete. Matériaux Constr 2(2):117-124. doi:10. 1007/BF02475099

46. Hobbs DW (1971) The dependence of the bulk modulus, Young's modulus, creep, shrinkage and thermal expansion of concrete upon aggregate volume concentration. Matériaux Constr 4(2):107-114. doi:10.1007/BF02473965

47. Granger L, Bažant ZP (1995) Effect of composition on basic creep of concrete and cement paste. J Eng Mech 121(11):1261. doi:10.1061/(ASCE)0733-9399(1995)121:11(1261)

48. Popovics S (1987) Quantitative deformation model for twophase composites including concrete. Mater Struct 20(3):171-179. doi:10.1007/BF02472733

49. Bažant ZP (1972) Prediction of Concrete Creep Effects Using Age-Adjusted Effective Modulus Method. J Am Concr Inst 69:212-217

50. Bažant ZP, Kim SS, ASCE F (1979) Approximate relaxation function for concrete. J Struct Div 105:2695-2705

51. Rilem TC 107 (1995) Guidelines for characterizing concrete creep and shrinkage in structural design codes or recommendations. Mater Struct 28:52-55

52. Bažant ZP, Li G (2008) Comprehensive database on concrete creep and shrinkage. Tech Rep 08, Infrastructure Technology Institute, McCormick School of Engineering and Applied Science, Northwestern University, Evanston

53. Bažant ZP, Prasannan S (1989) Solidification theory for concrete creep. I: formulation. J Eng Mech 115(8):16911703. doi:10.1061/(ASCE)0733-9399(1989)115:8(1691)
54. Bažant ZP, Prasannan S (1989) Solidification theory for concrete creep. II: verification and application. J Eng Mech 115(8):1704-1725. doi:10.1061/(ASCE)0733-9399(1989) $115: 8(1704)$

55. Wendner R, Hubler MH (2013) In: Bažant ZP, Ulm FJ, Jennings MH, Roland JMP (eds) mechanics and physics of creep, shrinkage, and durability of concrete. American Society of Civil Engineers, Cambridge, pp 429-436

56. Wendner R, Hubler MH, Bažant ZP (2015) Optimization method, choice of form and uncertainty quantification of Model B4 using laboratory and multidecade bridge databases. Mater Struct. doi:10.1617/ s11527-014-0515-0

57. Hubler MH, Wendner R, Bažant ZP (2015) Statistical justification of model B4 for drying and autogenous shrinkage of concrete and comparisons to other models. Mater Struct 48:797-814

58. RILEM TC-242-MDC (2015) Solidification theory for concrete creep. I: formulation. Mater Struct 48(4): 753

59. Bažant ZP, Baweja S (1995) Justification and refinements of model B3 for concrete creep and shrinkage 2. Updating and theoretical basis. Mater Struct 28(8):488-495. doi:10.1007/ BF02473171

60. Bentur A (2002) Cementitious materialsnine millennia and a new century: past, present, and future. J Mater Civ Eng 14(1):2. doi:10.1061/(ASCE)0899-1561(2002)14:1(2)

61. Popovics S (1993) Portland cement-fly ash-silica fume systems in concrete. Adv Cem Based Mater 1(2):83-91. doi:10.1016/1065-7355(93)90013-E

62. Brooks AG, Schindler AK, Barnes RW (2007) Maturity method evaluated for various cementitious materials. J Mater Civ Eng 19(12):1017-1025. doi:10.1061/(ASCE) 0899-1561(2007)19:12(1017)

63. Kim J, Han S, Song Y (2002) Effect of temperature and aging on the mechanical properties of concrete. part I Experimental results. Cem Concr Res 32(7):1087-1094. doi:10.1016/S0008-8846(02)00744-5

64. Han SH, Kim JK, Park YD (2003) Prediction of compressive strength of fly ash concrete by new apparent activation energy function. Cem Concr Res 33(7):965-971

65. Carino NJ, Tank RC (1992) Maturity function for concretes made with various cements and admixtures. Mater J 89(2):188-196

66. Kim J, Hunhan S, Kyunpark S (2002) Effect of temperature and aging on the mechanical properties of concrete. Part II Prediction model. Cem Concr Res 32(7):1095-1100

67. Browne RD, Blundell R (1969) The influence of loading age and temperature on the long term creep behaviour of concrete in a sealed, moisture stable, state. Matériaux Constr 2(2):133-143. doi:10.1007/BF02475101

68. McDonald J (1978) Creep of concrete under various temperature, moisture, and loading conditions. ACI Spec Publ 55:31-54. doi: $10.14359 / 6608$

69. Vandewalle L (2000) Concrete creep and shrinkage at cyclic ambient conditions. Cem Concr Compos 22(3):201-208. doi:10.1016/S0958-9465(00)00004-4

70. Hashin Z (1963) A variational approach to the theory of the elastic behaviour of multiphase materials. J Mech Phys Solids 11:127-140. doi:10.1016/0022-5096(63)90060-7 
71. Hill R (1965) A self-consistent mechanics of composite materials. J Mech Phys Solids 13:213-222. doi:10.1016/ 0022-5096(65)90010-4

72. Benveniste Y (1987) A new approach to the application of Mori-Tanaka's theory in composite materials. Mech Mater 6(2):147-157. doi:10.1016/0167-6636(87)90005-6

73. Baweja S, Dvorak GJ, Bažant ZP (1998) Triaxial composite model for basic creep of concrete. J Eng Mech 124(9): 959-965. doi:10.1061/(ASCE)0733-9399(1998)124:9(959)

74. Sanahuja J (2013) Effective behaviour of ageing linear viscoelastic composites: homogenization approach. Int $\mathbf{J}$ Solids Struct 50(19):2846-2856. doi:10.1016/j.ijsolstr. 2013.04.023

75. Lavergne F, Sab K, Sanahuja J, Bornert M, Toulemonde C (2015) Homogenization schemes for aging linear viscoelastic matrix-inclusion composite materials with elongated inclusions. Int J Solids Struct. doi:10.1016/j.ijsolstr. 2015.10.014

76. Larrard F, Roy R (1992) Relation entre formulation et quelques propriétés mécaniques des bétons à hautes performances. Mater Struct 25(8):464-475. doi:10.1007/ BF02472636

77. Pinho J, Ramos J, Florentino C (1988) Control of mass concrete for dams. Full-mixed and wet-screened concrete tests. In: ICOLD Congress. LNEC, San Francisco
78. Serra C, Batista AL, Tavares de Castro A (2012) Creep of dam concrete evaluated from laboratory and in situ tests. Strain 48(3):241-255. doi:10.1111/j.1475-1305.2011. 00818.x

79. Jansen R (2012) Advanced dam engineering for design, construction, and rehabilitation. Springer Science. URL: https:// books.google.com/books?id=xdZ5BgAAQBAJ\&pgis=1

80. Lamond JF (2006) Significance of tests and properties of concrete and concrete-making materials. ASTM International. URL:https://books.google.com/books?id=isTMHD 6yIy8C\&pgis $=1$

81. Sennour ML, Carrasquillo RL (1989) Creep and shrinkage properties in concrete containing fly ash. Tech rep, University of Texas, Austin

82. Bamforth PB (1980) In situ measurement of the effect of partial Portland cement replacement using either fly ash or ground granulated blast-furnace slag on the performance of mass concrete. Proc Instn Civ Engrs 69:777-800

83. Trebua F, Padevět P, Bittnar P (2012) Influence of Fly Ash Content in Cement Paste on Size of Creep. Procedia Eng 48:520-524 